NBER WORKING PAPER SERIES

THE EFFECTS OF EDUCATION QUALITY ON INCOME GROWTH AND MORTALITY DECLINE

\author{
Eliot A. Jamison \\ Dean T. Jamison \\ Eric A. Hanushek \\ Working Paper 12652 \\ http://www.nber.org/papers/w12652
}
NATIONAL BUREAU OF ECONOMIC RESEARCH
1050 Massachusetts Avenue
Cambridge, MA 02138
October 2006

An earlier version of this paper was presented at the International Conference on the Economics of Education, Dijon, France, June 2006. We are grateful for comments from Richard Feachem, Kenneth Hill, Emmanuel Jimenez, Maureen Lewis, Walter MacMahon, Michael Seltzer, Yeo Meng Thum, Jia Wang, Ludger Woessmann, and seminar participants at UCLA. Financial support was provided by the Disease Control Priorities Project through the Fogarty International Center of the U.S. National Institutes of Health and by the Packard Humanities Institute. The views expressed herein are those of the author(s) and do not necessarily reflect the views of the National Bureau of Economic Research.

(C) 2006 by Eliot A. Jamison, Dean T. Jamison, and Eric A. Hanushek. All rights reserved. Short sections of text, not to exceed two paragraphs, may be quoted without explicit permission provided that full credit, including () notice, is given to the source. 
The Effects of Education Quality on Income Growth and Mortality Decline

Eliot A. Jamison, Dean T. Jamison, and Eric A. Hanushek

NBER Working Paper No. 12652

October 2006

JEL No. F4,I2,J0,J21,O4,I1

\begin{abstract}
$\underline{\text { ABSTRACT }}$
Previous work shows that higher levels of education quality (as measured by international student achievement tests) increases growth rates of national income. This paper begins by confirming those findings in an analysis involving more countries over more time with additional controls. We then use the panel structure of our data to assess whether the mechanism by which education quality appears to improve per capita income levels is through shifting the level of the production function (probably not), through increasing the impact of an additional year of education (probably not), or through increasing a country's rate of technological progress (very likely). Mortality rates complement income levels as indicators of national well-being and we extend our panel models to show that improved education quality increases the rate of decline in infant mortality. Throughout the analysis, we find a stronger impact of education quality and of years of schooling in open than in closed economies.
\end{abstract}

Eliot A. Jamison

Origo, Inc.

153 Kearny St., Suite 401

San Francisco, CA 94108

ejamison@origoinc.com

Dean T. Jamison

University of California, San Francisco

50 Beale St., Suite 1200

San Francisco, CA 94105

djamison@globalhealth.ucsf.edu
Eric A. Hanushek

Hoover Institution

Stanford University

Stanford, CA 94305-6010

and NBER

hanushek@stanford.edu 


\section{THE EFFECTS OF EDUCATION QUALITY ON INCOME GROWTH AND MORTALITY DECLINE}

by

Eliot A. Jamison, Dean T. Jamison, and Eric A. Hanushek

\section{Background}

The impact of education on the level and growth rate of income has been the subject of much study and debate. One recent innovation allows for heterogeneity in the quality of education. Hanushek and Kimko (2000) use international student achievement tests (ISATs) in mathematics and science to measure the quality of a country's educational system and relate this to per capita income growth. They find a strong positive link between educational quality and a country's GDP growth rate that appears to be causal. ${ }^{*}$ In this paper, we build on previous work in a number of important ways to show the central importance of education quality.

First, reflecting the availability of test score data for a significantly larger number of countries, we assess the robustness of earlier results to an expanded sample of countries. Second, we adapt models used by Jamison, Lau and Wang (2005) that allow for heterogeneity in country effects to assess the strength of alternative mechanisms through which education quality may affect income. Specifically, we test whether educational quality may operate through the level of output (country fixed effects), through the rate of technical progress, or through the size of the increment to output caused by an increase in a country's average quantity of education. Third, this paper initiates an assessment of the extent to which education quality plays a role in reducing mortality. In addition to being an important policy topic in its own right, health outcomes are a natural place to look for the returns to schooling investments. Moreover, the fundamental issues of causation and measurement that are key to economic growth have close parallels in analyzing changes in health outcomes across countries. Drawing upon these similarities, we

\footnotetext{
* Causation is discussed extensively in Bils and Klenow (2000); measurement issues are discussed in Hanushek and Kimko (2000), Krueger and Lindahl (2001), and Cohen and Soto (2001).
} 
present preliminary estimates of how the level and quality of education affect the rate of infant mortality decline.

We begin with an overview of the data used in our analyses (Section 2). Section 3 replicates and extends the work of Hanushek and Kimko (2000) on the effects of education quality on economic growth. It goes beyond the earlier work by taking advantage of new ISATs, by extending the time period of the analysis, by comparing ISATs as measures of quality with a measure introduced by Bratsberg and Terrell (2002) that uses labor force data, and, importantly, by introducing a control for the possibility that test scores simply mirror the general quality of institutions and policies in a country. Section 4 takes advantage of the panel structure of much of our data to assess the relative strength of our three hypotheses concerning the mechanisms through which education quality could be having an impact. Section 5 extends the analysis to assessing the role of education and education quality in facilitating decline in infant mortality and Section 6 draws conclusions.

\section{Data}

Our data set contains up to 62 countries at 10-year intervals from 1960-2000, although missing data makes the analytical samples smaller. Several variables provide both economic outcomes and what might be labeled standard inputs to cross-country growth models for each decade including GDP per capita (YPC), capital stock per capita (KPC), the total fertility rate (TFR), and years of education (ED). Other important country characteristics are only available with one observation per country: fraction of land area in the tropics (TROPICAL) and openness to trade (OPEN). Finally, we have two education quality variables (again available with one observation per country): mathematics test scores (EQTEST) and US labor market returns to education by country of immigrant origin (EQBT). For countries with basic economic data, there are 54 countries with EQTEST available and 62 countries with EQBT available.

The interpretation of mathematics test scores as measure of the quality of education is straightforward. They are a direct measure of the amount of learning that has taken place after a given number of years of schooling. The US labor market returns to education for immigrants are a less direct 
measure of quality. However, we think that this interpretation (originally suggested by Bratsberg and Terrell, 2002) is plausible and justified. ${ }^{\dagger}$ This is supported by the link that Bratsberg and Terrrel find between US labor market returns and school inputs. In the sample for which both EQTEST and EQBT are available, the correlation between the two is 0.44 .

Definitions and sources for all our variables, as well as summary statistics, appear in Appendix A. Appendix B provides further information on the education years and education quality variables.

\section{Education Quality and Growth in Income, 1960-2000}

Our first task is simply to ascertain whether the previously estimated relationships between growth and labor force quality hold up to new data and further scrutiny. We consider several aspects of this related to basic data, to country samples, and to time period of observation.

As empirical work on growth has developed, a variety of questions about the basic underlying data have arisen. The concern about the data has several components. The basic measurement of education levels is surprisingly difficult to develop on a consistent and accurate basis. The first thorough data development by Barro and Lee (2001) has been modified and extended by Cohen and Soto (2001), which is used here.

More importantly, in measuring labor force quality we pursue two separate approaches. The first extends the data set on ISATs originally assembled by Hanushek and Kimko (2000) and by Barro and Lee (2001). The second relies on earnings data from immigrants to the U.S. to indicate which countries have a strong school system as identified by Bratsberg and Terrell (2002).

The ISAT data set has been improved in important ways. Most significantly, recent international testing has both expanded the sample of countries and has added new observations for existing countries.

\footnotetext{
${ }^{\dagger}$ The primary factor, other than quality, that might cause differences in US labor market returns between immigrants from different countries is how "transferable" that country's education is to a US context. It is possible that some countries educational system create habits and ways of thinking that are more likely to lead to success in the US labor market but are not reflective of inherent quality or productivity differences. The most obvious of these is English language ability. Bratsberg and Terrell control for English language ability when calculating their returns. While there may be other, unaccounted for, factors, it seems likely that a substantial fraction of the cross country variation results from variation in schooling quality.
} 
Specifically, instead of the 31 countries in Hanushek and Kimko (2000), we now have 45 countries which have both test information and economic information for the relevant period. ${ }^{\ddagger}$

The ISAT data, however, present a series of challenges when one wants to compare results over time (either for an individual country or for a sample of different countries). Each test that has been given involves a different sample of countries and schools. This sampling is not problematic per se but becomes an issue because no effort is made to equate the tests and to aggregate them over time. Since the country sample and test vary, it is not possible to assume the questions are equal in difficulty or that the range of performance is the same over time. This paper uses the measurement research by Hanushek and Wößmann (2006), who develop a common metric of scores through two data refinements. First, because the United States has both participated in all of the international tests and has maintained its own longitudinal testing, the U.S. international performance over time can be calibrated to the external standard - thus benchmarking each of the separate international tests. Second, while this provides a relative comparison of countries taking each test over time, it is also necessary to establish the variance on the tests so that direct compatibility of countries taking different tests can be established. The calibration of the dispersion of the tests relies on holding the score variance constant within a group of countries with stable education systems (defined in terms of attendance rates) over time. For this, the 13 OECD countries that had half or more students completing upper secondary around the beginning of international testing in the 1970s are used as the "stable" country group. Variances are standardized to the across student variance in performance on the 2000 PISA tests for the pool of students from these 13 countries. The details of transformation are found in Appendix B and, more fully, in Hanushek and Wößmann (2006)..$^{\S}$

Our ISAT measure is the simple average of calibrated mathematics test performance on all tests in which a country participated. While this approach misses any secular changes in performance, the

\footnotetext{
‡ Hanushek and Kimko (2000) extended their country sample by projecting test scores for close to 50 countries that did not participate in the international testing through the early 1990s. That approach is not pursued here.

$\S$ This approach extends the quality comparisons in Hanushek and Kimko (2000) through the development of a normalization for the variance of different tests.
} 
thinness of available information does not permit any alternatives. Importantly, this measure encompasses overall skills, not just those developed in schools. Thus, whether skills are developed at home, in schools, or elsewhere, they are included in the growth modeling.

A complementary approach to measuring quality was developed by Bratsberg and Terrell (2002). They use microdata from the 1980 and 1990 U.S. Census of Population to estimate log wage models where the impact of a year of schooling varies by where the individual was born and received schooling. ${ }^{* *}$ By normalizing returns to years of schooling in the United States, it is possible to compare the relative labor market performance of immigrants coming from different schooling systems. An advantage of this methodology is that it provides a wider range of countries for inclusion in the growth analysis, while a disadvantage is that it includes just the effects of formal schooling (and things correlated with school attainment). We test this labor market based measure of quality as an alternative to the ISAT measures.

The second major goal of our new work is the expansion of the analysis in two dimensions. First, we add additional countries, largely by the new data on quality discussed above. The country data expand from 31 in Hanushek and Kimko (2000) to 45 with ISAT measures and to 54 using the Bratsberg and Terrell (2002) data. Expanding on the time dimension is equally important. While much of the original modeling of growth relationships looked through 1990, the 1990s saw a number of international economic changes that might affect measured growth rates and the underlying estimation. The East Asian currency crisis is perhaps most notable, because the East Asian countries have also done extraordinarily well on international mathematics tests, but changes of economic fortune for other countries are also important. $^{\dagger \dagger}$

\footnotetext{
** Estimation includes a variety of other controls including age, age squared, English fluency, and region of residence.

${ }^{\dagger \dagger}$ Hanushek and Kimko (2000) investigate whether the achievement results could potentially be caused largely by the East Asian countries with both rapid growth and high achievement. This is discussed below.
} 
Table 1 provides the most parsimonious models, ones that mirror the estimation in Hanushek and

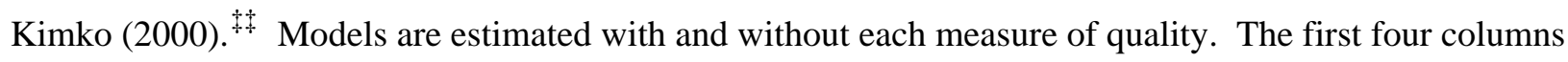
cover the simplest model, stripped down to look similar to the basic Hanushek and Kimko (2000) results. The final four columns include simple additions: the fertility rate, a measure of the openness of the economy, and an indicator for being a tropical country.

The first two columns show clearly that the results of all of the basic extensions combined are extraordinarily similar to those in Hanushek and Kimko (2000). In particular, the models show the standard result of conditional convergence with higher initial income yielding lower growth rates. They also show that quantity of schooling has a strong positive effect that is substantially reduced once quality is considered. Importantly, quality measured by ISATs shows a strongly positive influence on growth. ${ }^{\S \S}$ Moreover, the explained variance in growth rates across countries doubles when quality is added.

The magnitudes are quite similar to those previously estimated for the smaller set of countries. With a standard deviation of 57.1 at the country level on EQTEST, the test impact in model 2 (Table 1) indicates that one standard deviation higher test performance would yield 0.87 percent higher annual growth rates. Hanushek and Kimko (2000) found that this impact was around one percent. The impact of cognitive skills is reduced by inclusion of the added measures of country differences, falling to 0.45 percent annual growth per standard deviation (model 6). However, this lower impact is arguably more reasonable, because the original Hanushek and Kimko (2000) estimates appear very high.

In contrast, the Bratsberg and Terrell (2002) quality measure is not significant at conventional levels in the most basic model and becomes close to zero and insignificant in the models including other components of heterogeneity. Given these results, the remainder of the paper concentrates on the ISAT based quality measure (EQTEST).

\footnotetext{
抹 This estimation follows the same basic specification of Hanushek and Kimko, which relate growth rates to the level of scores - implying a form of endogenous growth models. This form is relaxed below.

$\S \S$ Note that we use measures of the quantity of schooling at the beginning of the period (i.e., 1960) to avoid the problems of simultaneity that have been pointed out by a number of authors including Bils and Klenow (2000). This specification does, however, introduce the possibility of missing important elements of the expansion of schooling during the period of growth.
} 
Table 1: Education and Education Quality as Determinants of the Growth Rate of Income Per Capita, 1960-2000

\begin{tabular}{|c|c|c|c|c|c|c|c|c|}
\hline \multirow[b]{2}{*}{ Variable } & \multicolumn{8}{|c|}{ Models } \\
\hline & 1 & 2 & 3 & 4 & 5 & 6 & 7 & 8 \\
\hline Constant & $\begin{array}{c}1.937 \\
(5.17)\end{array}$ & $\begin{array}{r}-4.164 \\
(3.40)\end{array}$ & $\begin{array}{l}2.040 \\
(6.66)\end{array}$ & $\begin{array}{l}1.191 \\
(2.23)\end{array}$ & $\begin{array}{l}4.506 \\
(4.03)\end{array}$ & $\begin{array}{l}0.763 \\
(0.44)\end{array}$ & $\begin{array}{l}4.825 \\
(5.61)\end{array}$ & $\begin{array}{l}4.714 \\
(5.13)\end{array}$ \\
\hline YPC60 & $\begin{array}{r}-0.367 \\
(3.97)\end{array}$ & $\begin{array}{r}-0.327 \\
(4.44)\end{array}$ & $\begin{array}{r}-0.266 \\
(3.29)\end{array}$ & $\begin{array}{r}-0.319 \\
(3.82)\end{array}$ & $\begin{array}{r}-0.376 \\
(5.55)\end{array}$ & $\begin{array}{r}-0.349 \\
(5.49)\end{array}$ & $\begin{array}{r}-0.328 \\
(5.45)\end{array}$ & $\begin{array}{r}-0.332 \\
(5.36)\end{array}$ \\
\hline ED60 & $\begin{array}{l}0.459 \\
(4.00)\end{array}$ & $\begin{array}{c}0.249 \\
(2.50)\end{array}$ & $\begin{array}{c}0.327 \\
(3.27)\end{array}$ & $\begin{array}{c}0.281 \\
(2.80)\end{array}$ & $\begin{array}{c}0.100 \\
(0.94)\end{array}$ & $\begin{array}{l}0.071 \\
(0.72)\end{array}$ & $\begin{array}{c}0.032 \\
(0.35)\end{array}$ & $\begin{array}{l}0.024 \\
(0.25)\end{array}$ \\
\hline EQTEST & & $\begin{array}{r}0.0153 \\
(5.14)\end{array}$ & & & & $\begin{array}{r}0.0078 \\
(2.71)\end{array}$ & & \\
\hline EQBT & & & & $\begin{array}{c}0.298 \\
(1.92)\end{array}$ & & & & $\begin{array}{l}0.046 \\
(0.37)\end{array}$ \\
\hline TFRAVG & & & & & $\begin{array}{r}-0.462 \\
(2.15)\end{array}$ & $\begin{array}{r}-0.362 \\
(1.79)\end{array}$ & $\begin{array}{r}-0.411 \\
(2.65)\end{array}$ & $\begin{array}{r}-0.421 \\
(2.65)\end{array}$ \\
\hline OPEN & & & & & $\begin{array}{l}1.853 \\
(3.89)\end{array}$ & $\begin{array}{l}1.482 \\
(3.22)\end{array}$ & $\begin{array}{l}1.466 \\
(3.75)\end{array}$ & $\begin{array}{l}1.432 \\
(3.54)\end{array}$ \\
\hline TROPICAL & & & & & $\begin{array}{r}-0.587 \\
(1.39)\end{array}$ & $\begin{array}{r}-0.324 \\
(0.80)\end{array}$ & $\begin{array}{r}-0.837 \\
(2.72)\end{array}$ & $\begin{array}{c}-0.783 \\
(2.27)\end{array}$ \\
\hline $\mathrm{N}$ & 45 & 45 & 54 & 54 & 43 & 43 & 53 & 53 \\
\hline R-Squared & 0.285 & 0.561 & 0.182 & 0.237 & 0.698 & 0.748 & 0.635 & 0.636 \\
\hline
\end{tabular}

Notes: $\quad 1$. The dependent variable is the average annual growth rate in per capita income from 1960 to 2000, expressed in \% per year (YPCGR).

2. $t$-values are shown in parenthesis below the estimated coefficients. 
In terms of the overall model, openness of the economy (OPEN) has a powerful and significant effect on growth rates. Moving from a closed economy to a fully open economy is estimated to add almost $1 \frac{1}{2}$ percentage points to annual growth rates, consistent with findings of Sachs and Warner (1997a). Moreover, this finding is robust to alternative measures such as institutional capacity or globalization (Appendix A discusses these issues further). Higher fertility rates and being located in the tropics significantly detracts from growth. Interestingly, in the more complete models (columns 5-8) quantity of schooling is found to have a very small and insignificant effect on growth. This finding parallels that of Hanushek and Kimko (2000) where the effect of quantity of schooling was sharply reduced by including explicit measures of cognitive skills.

The concerns about causality in the relationship of cognitive skills and growth have been addressed in detail by Hanushek and Kimko (2000). They conclude that causation concerns are very different in the case of quality than quantity, being much less of an issue in interpreting the results. Because causality issues are important throughout this paper, we describe the Hanushek and Kimko direct investigations.

One common concern in analyses such as this is that schooling might not be the actual cause of growth but, in fact, may just reflect other attributes of the economy that are beneficial to growth. For example, the East Asian countries consistently score very highly on the international tests and also had extraordinarily high growth over the 1960-1990 period. It could be that other aspects of these East Asian economies drove their growth and that the growth analysis simply is picking out these countries. But in fact, even if the East Asian countries are excluded from the analysis, a strong—albeit slightly smallerrelationship is still observed with test performance.

Another possibility is that other factors that affect growth, such as efficient market organizations, are also associated with efficient and productive schools — so that, again, the test measures are really a proxy for other attributes of the country. To investigate this, Hanushek and Kimko (2000) concentrate on immigrants to the United States who received their education in their home countries. They find that, other things equal, immigrants who were schooled in countries that have higher scores on the 
international math and science examinations earn more in the United States. On the other hand immigrants receiving part or all of their schooling in the United States do not see any earnings advantage linked to the cognitive skills of their home country.

Finally, the observed relationships could simply reflect reverse causality, that is, that countries that are growing rapidly have the resources necessary to improve their schools and that better student performance is the result of growth, not the cause of growth. As a simple test of this, Hanushek and Kimko (2000) investigated whether the international math and science test scores were systematically related to the resources devoted to the schools in the years prior to the tests. They were not.

\section{Possible Mechanisms for the Effect of Education Quality on Income ${ }^{* * *}$}

The results in Table 1 point to a strong association between education quality, as measured by ISATs and economic outcomes, and the discussion suggests that there is good reason to believe this to be causal. In this section we explore potential mechanisms for this effect. One of the mechanisms for the effect of education quality is through its effect on technical progress. The other mechanisms that we assess are potential quality determinants of country fixed effects in the production function and of the magnitude of a year of education's impact on income. We begin by describing a panel model of the determinants of income levels that allows for cross-country heterogeneity in the constant term (fixed effect), in the education coefficient and in the time trend (technical progress). We model the mechanism for the effect of education quality by allowing quality to affect the magnitude of these coefficients.

\subsection{The Extended Model}

In order to model income level in a panel data set we use the "meta-production function" approach developed by Lau and his co-workers in a series of studies of the sources of economic growth in both high-income and East Asian countries. ${ }^{\dagger \dagger}$ For an overview of methods and

\footnotetext{
*** The approach and modeling of this section draw heavily on the framework introduced by Jamison, Lau and Wang (2005).

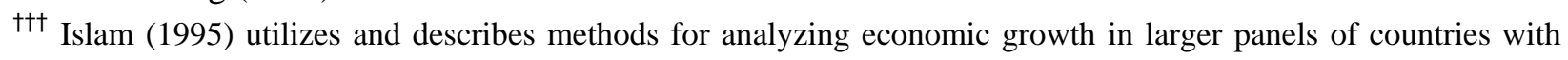
fewer time observations. His emphasis is on accounting for country fixed effects. Lee, Pesaran and Smith (1997)
} 
findings, see Lau (1996) and Boskin and Lau (1992, 2000). If data are available for many time points for a sufficient number of countries, the flexibility of the transcendental logarithmic (translog) production function allows estimation of critical country-specific parameters (e.g. rates of technical progress) along with separation of the level and bias of technical progress from scale effects. Our analysis includes many developing countries in a much larger sample of countries than was studied by Boskin and Lau. This limits data availability to 10-year intervals and precludes use of the highly data intensive translog formulation. In this paper we closely follow the methods of Jamison, Lau and Wang (2005) and estimate variants of a Cobb-Douglas specification.

In order to allow for cross-country variation in specific coefficients of interest we use multilevel modeling techniques, specifically, Hierarchical Linear Modeling (HLM)

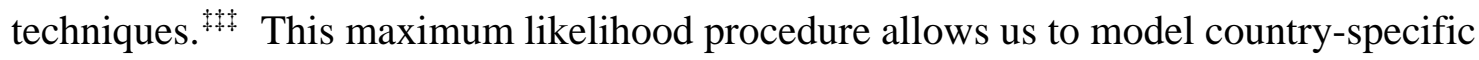
intercepts and the associated complex error structure. The simplest HLM specification that we use is similar to a generalized least squares (GLS) estimated random effects model when we impose a common production function across countries (while allowing for a country specific intercept). We also employ a more generalized HLM procedure that allows estimation of country-time interactions (i.e. of country-specific technical progress in a Cobb-Douglas framework). Central to the purposes of this paper, it allows us to explore potential determinants of both the cross-country variation in technical progress and in the coefficient on education. . $^{\S \S}$

extend Islam's work by allowing for country-specific rates of technical progress and, additionally, Lee, Pesaran and Smith (1998) provide a succinct account of the similarities and differences of the two..

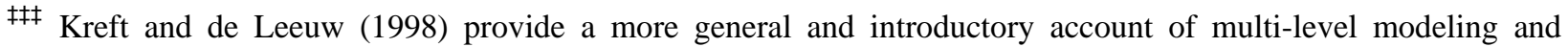
Raudenbusch et al (1999) document the software package that we use.

$\S \S \S$ Temple (1999) points to parameter heterogeneity in general as a major problem to be dealt with in the empirical growth literature. Krueger and Lindahl (2001) undertake a preliminary exploration of heterogeneity in the education coefficient. 
To capture heterogeneity in country coefficients, our aggregate production function is given by equation (1). This supplemented with equations (3) - (5), which are estimated simultaneously with equation 1 and which seek to explain the country-specific intercepts $\left(\beta_{0 \mathrm{i}}\right)$, rates of technical progress $\left(\beta_{1 \mathrm{i}}\right)$ and effects of education $\left(\beta_{2 \mathrm{i}}\right)$ in equation (1):

$$
\text { LYPC }_{i t}=\beta_{0 i}+\beta_{1 i} \text { TIME }_{t}+\beta_{2 i} \text { ED }_{i t}+\beta_{3} \text { LKPC }_{i t}+\beta_{4} \text { LTFR }_{\text {it }}+\varepsilon_{\text {it }},
$$

where the variables and coefficients signify:

LYPC $_{\mathrm{it}}$ : $\quad$ the natural log of average per capita GDP in country $i$ at time $t$;

TIME $_{\mathrm{t}}$ : $\quad$ the number of years lapsed since $1960(t-1960)$;

$\mathbf{L K P C}_{\mathrm{it}}$ : $\quad$ the natural log of average per capita physical capital in country $i$ at time $t$;

$\mathbf{E D}_{\mathrm{it}}$ : $\quad$ the average number of years of education in the adult population (aged 15 to 64 ) of country $i$ at time $t$;

$\mathbf{L T F R}_{\mathrm{it}}$ : $\quad$ the natural $\log$ of the total fertility rate in country $i$ at time $t$;

$\beta_{0 \mathrm{i}}$ : the country-specific intercept for country $i$;

$\beta_{1 \mathrm{i}}$ : the effect of 'technical progress' in increasing income per capita in country $i$;

$\beta_{2 \mathrm{i}}$ : the impact on income of education in country $i$;

$\beta_{3}: \quad$ the elasticity of income with respect to physical capital;

$\beta_{4}$ : the elasticity of income with respect to the total fertility rate; and

$\varepsilon_{\mathrm{it}}$ : the unexplained residual for country $i$ at time $t$, assumed to be normally distributed with mean 0 .

Assuming a common intercept and common time and education coefficients for all countries (i.e. assuming $\beta_{0 \mathrm{i}}=\beta_{0 \mathrm{j}}, \quad \beta_{1 \mathrm{i}}=\beta_{1 \mathrm{j}}$ and $\beta_{2 \mathrm{i}}=\beta_{2 \mathrm{j}}$ for all $i, j$ ), equation 1 has the model specification for an ordinary least squares (OLS) regression. To make the above equation similar to a random-effects regression, to be estimated by generalized least squares, one can supplement equation 1 with:

$$
\beta_{0 \mathrm{i}}=\gamma_{00}+\mu_{0 \mathrm{i}}
$$


where $\mu_{0 \mathrm{i}}$ is assumed to be normally distributed with mean zero and uncorrelated with the unexplained residual for the country $\varepsilon_{\mathrm{it}}$; in other words, the covariance between them is zero $\left[\operatorname{Cov}\left(\mu_{0 \mathrm{i}}, \varepsilon_{\mathrm{it}}\right)=0\right]$. This allows estimation of country-specific intercepts since the random variable $\mu_{0 \mathrm{i}}$ is the deviation of country i's mean from the overall mean. To model potential determinants of the country intercept, we can use the random-intercept specification in HLM:

$$
\beta_{0 i}=\gamma_{00}+\gamma_{01} \text { TROPICAL }_{i}+\gamma_{02} \text { EQTEST }_{i}+\mu_{0 i}
$$

The right-hand-side variables chosen here include the fraction of a country's land area situated within the

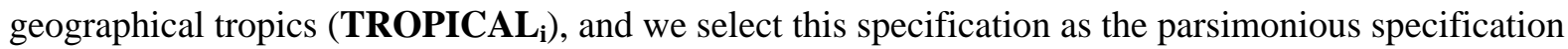
from Jamison, Lau and Wang (2005), while also including EQTEST . $_{\mathbf{i}}$

HLM provides a practical Bayesian algorithm for modeling potential determinants of countryspecific coefficients on other variables and, because of the central importance of technical progress, we model its coefficient (i.e. the coefficient on time) as a function of EQTEST and OPEN (the fraction of years the country was deemed to have an open economy - Sachs and Warner, 1997a and 1997b). Specifically,

$$
\beta_{1 \mathrm{i}}=\gamma_{10}+\gamma_{11} \text { EQTEST }_{\mathrm{i}}+\gamma_{12} \text { OPEN }_{\mathrm{i}}+\mu_{1 \mathrm{i}}
$$

Another potential mechanism for the effect of EQTEST on income is through affecting the productivity of a year of education, and we model this in equation (5):

$$
\beta_{2 i}=\gamma_{20}+\gamma_{21} \text { EQTEST }_{i}+\gamma_{22} \text { OPEN }_{i}+\mu_{2 i}
$$




\subsection{Statistical Results}

Tables 2 to 4 report the main results of our analysis based on estimation of an aggregate production function for 51 countries based on data at 10-year time intervals between 1960 and 2000 . Table 2 presents the basic estimates of aggregate production functions. Table 3 goes beyond Table 2 by reporting on our estimates of the magnitude of selected determinants of why education coefficients differ across countries (equation 5), and Table 4 assesses potential reasons why the rate of technical progress varies.

As indicated previously, the models reported in this section are estimated by maximum likelihood using the HLM algorithm, and model 9, Table 2, reports the basic HLM results in a close analog to a GLS-estimated random effects model. Model 10 reports estimation of equation (3) and suggests that EQTEST has little effect on the country-specific intercepts.. Models 11 and 12 repeat models 9 and 10 except that we fix the coefficient on physical capital at 0.35 (i.e. we subtract 0.35 times the amount of (log) physical capital from our dependent variable before estimating the equations). This follows Topel (1999), Krueger and Lindahl (2001) and others and results in sharper estimates of the effect of education and fertility, as well as eliminating the implausibly high estimates of the physical capital coefficients in models 9 and 10. EQTEST remains unimportant although the estimated coefficients on education increase substantially. We have undertaken our analyses both with the physical capital coefficient fixed and allowing for it to be estimated. Our relevant findings are generally robust with respect to this choice and, from this point, we report only results that have fixed the capital coefficient at 0.35 .

Models 13 and 14 in Table 2 repeat model 11 but relax the model 11 assumption that the coefficients on education and on time are identical for all countries. Model 13 shows the effect of allowing country-specific education coefficients; there is relatively little effect on other coefficients except to sharpen the estimated (adverse) effect of tropical location on income. (Appendix Table C1 reports the country specific estimates of the education coefficient and shows those estimates to bear little relation to the estimates of the private rate of return to education based on studies of the determinants of 
Table 2: Determinants of Income Levels, 1960-2000

(51 countries, 255 observations)

\begin{tabular}{|c|c|c|c|c|c|c|}
\hline \multirow[b]{2}{*}{ Independent Variable } & \multicolumn{6}{|c|}{ Models } \\
\hline & 9 & 10 & 11 & 12 & 13 & 14 \\
\hline \multicolumn{7}{|c|}{ I. Time-invariant determinants of income level: } \\
\hline Constant & $\begin{array}{l}3.710 \\
(7.18)\end{array}$ & $\begin{array}{l}3.924 \\
(6.34)\end{array}$ & $\begin{array}{r}5.186 \\
(20.91)\end{array}$ & $\begin{array}{r}5.404 \\
(11.85)\end{array}$ & $\begin{array}{r}5.042 \\
(22.71)\end{array}$ & $\begin{array}{r}4.952 \\
(23.64)\end{array}$ \\
\hline TROPICAL & $\begin{array}{r}-0.070 \\
(0.78)\end{array}$ & $\begin{array}{r}-0.083 \\
(1.00)\end{array}$ & $\begin{array}{r}-0.150 \\
(1.56)\end{array}$ & $\begin{array}{r}-0.164 \\
(1.82)\end{array}$ & $\begin{array}{r}-0.226 \\
(2.45)\end{array}$ & $\begin{array}{r}-0.217 \\
(2.17)\end{array}$ \\
\hline EQTEST & & $\begin{array}{r}-0.0005 \\
(0.58)\end{array}$ & & $\begin{array}{r}-0.0005 \\
(0.51)\end{array}$ & & \\
\hline
\end{tabular}

II. Time-varying determinants of income level:

\begin{tabular}{|c|c|c|c|c|c|c|c|}
\hline TIME & & $\begin{array}{r}0.0047 \\
(2.33)\end{array}$ & $\begin{array}{r}0.0043 \\
(1.80)\end{array}$ & $\begin{array}{r}0.0038 \\
(1.81)\end{array}$ & $\begin{array}{r}0.0034 \\
(1.37)\end{array}$ & $\begin{array}{r}0.0039 \\
(1.59)\end{array}$ & \\
\hline TIME & $\begin{array}{l}\text { (average of country-specific } \\
\text { estimates) }\end{array}$ & & & & & & $\begin{array}{r}0.0065 \\
(3.71)\end{array}$ \\
\hline LKPC & & $\begin{array}{r}0.535 \\
(11.94)\end{array}$ & $\begin{array}{r}0.535 \\
(12.02)\end{array}$ & $\begin{array}{r}0.350^{\mathrm{a}} \\
\mathrm{NA}\end{array}$ & $\begin{array}{r}0.350^{\mathrm{a}} \\
\mathrm{NA}\end{array}$ & $\begin{array}{r}0.350^{\mathrm{a}} \\
\mathrm{NA}\end{array}$ & $\begin{array}{r}0.350^{\mathrm{a}} \\
\mathrm{NA}\end{array}$ \\
\hline ED & & $\begin{array}{l}0.025 \\
(1.75)\end{array}$ & $\begin{array}{r}0.028 \\
(1.81)\end{array}$ & $\begin{array}{l}0.075 \\
(4.84)\end{array}$ & $\begin{array}{l}0.078 \\
(4.28)\end{array}$ & & $\begin{array}{l}0.080 \\
(5.50)\end{array}$ \\
\hline ED & $\begin{array}{l}\text { (average of country-specific } \\
\text { estimates) }\end{array}$ & & & & & $\begin{array}{l}0.083 \\
(5.06)\end{array}$ & \\
\hline LTFR & & $\begin{array}{r}-0.178 \\
(1.56)\end{array}$ & $\begin{array}{r}-0.185 \\
(1.59)\end{array}$ & $\begin{array}{r}-0.250 \\
(2.14)\end{array}$ & $\begin{array}{l}-0.257 \\
(2.18)\end{array}$ & $\begin{array}{r}-0.203 \\
(1.90)\end{array}$ & $\begin{array}{r}-0.096 \\
(1.12)\end{array}$ \\
\hline
\end{tabular}

$\underline{\text { Model Statistics }}$

Number of parameters estimated

$\begin{array}{rrrrrr}8 & 9 & 7 & 8 & 9 & 9 \\ -61.3 & -61.7 & -31.5 & -31.8 & -51.6 & -94.9\end{array}$

a Coefficient on LKPC constrained to equal 0.35 .

b "Deviance" is twice the negative log-likelihood value associated with the maximum likelihood parameter estimates. The larger the deviance, the poorer the fit.

Notes: $\quad$ 1. The dependent variable is the logarithm of income per capita (LYPC).

2. t-values are shown in parenthesis below the estimated coefficients. 
individual earnings.) We attribute this to distortions in labor markets, particularly in developing countries. Model 14 shows the effect of allowing technical progress to be country specific. The average magnitude of technical progress increases and the estimated impact of TFR declines. The deviance statistic indicates that model 13 and, particularly, model 14 improve substantially on model 11 . The remainder of this section explores potential determinants of the coefficient variability that models 13 and 14 indicate to be important.

Models 15 through 22 in Tables 3 and 4 convey our main results concerning, respectively, the determinants of the education and time coefficients. Results for each model are divided into three categories: time-invariant determinants of income level, time-varying determinants of income level and determinants of the country-specific education coefficient (Table 3) or rate of technical progress (Table 4). The time-invariant determinants of income level consist of: an intercept term that is common to all countries ( $\gamma_{00}$ in equation 3); an effect due to TROPICAL i.e. a measure of the extent to which being tropical affects the level of a country’s income; and a third country-specific "fixed" effect $\left(\mu_{0 \mathrm{i}}\right.$ in equation 3) that is not reported in Tables 2 to 4 . Being fully in the tropics (TROPICAL $=1$ ) is estimated to result in a downward shift in income level of between 16 and 25 percent, depending on the model (in Table 4), relative to an otherwise similar country from entirely outside the tropics. (Radelet, Sachs and Lee (1997) and Hall and Jones (1999) find somewhat larger adverse effects from a tropical location.)

The next category of determinants consists of time-varying ones for each country - levels of fertility and physical capital and (in Table 4) education. The coefficients are to be interpreted in the standard way, e.g. in model 15 the elasticity of income level with respect to TFR is $\quad-0.23$. Bloom and Williamson (1998) concluded that population growth affects economic growth principally when the dependent and working-age populations have different growth rates. In light of their findings, we included the total fertility rate (TFR) in the model to proxy the characteristics of the country age 
Table 3: Determinants of Income and of Country-Specific Estimates of the Coefficient of Education on Income

(51 countries, 255 observations, 1960-2000)

\begin{tabular}{ccccc}
\hline & \multicolumn{5}{c}{ Models } \\
\cline { 2 - 6 } Independent Variable & 15 & 16 & 17 & 18 \\
\hline \hline
\end{tabular}

I. Time-invariant determinants of income level:

Constant

TROPICAL

II. Time-varying determinants of income level:

TIME

LKPC

LTFR

III. Determinants of returns to schooling:

Constant

EQTEST

OPEN

EQOPEN (interaction between EQTEST and OPEN)

$\begin{array}{rrrr}5.111 & 5.215 & 5.225 & 5.216 \\ (21.82) & (23.78) & (23.74) & (24.55) \\ -0.129 & -0.210 & -0.182 & -0.217 \\ (1.45) & (2.49) & (1.94) & (2.74)\end{array}$

5.216

.


structure: countries with high TFR will tend to have a high ratio of dependent to working age population which, in the production function formulation, should adversely affect per capita output levels.

The third block of coefficients in Tables 3 and 4 shows our estimates of the effects of several factors likely to be influencing the education coefficient (Table 3, which reports estimation of equation (5)) and the rate of technical progress or diffusion (Table 4, reporting estimation of equation (4)). Model 15 in Table 3, for example indicates that EQTEST has a statistically significant impact on the size of a country's education coefficient: it suggests that higher quality schooling results in a greater economic impact for a year of education. Model 16 similarly suggests that schooling pays off more in open economies than in closed ones. In a fully open economy the coefficient on schooling would be about 0.08 and in a fully closed economy it would be about 0.02. Model 17 enters both EQTEST and OPEN as determinants of the schooling coefficient and with this specification the effect of EQTEST is close to zero. OPEN, however, remains statistically significant, and the estimated size of the education coefficient in open and non-open countries as calculated from model 17 is about the same as from model 16. Model 18 adds an interaction between EQTEST and OPEN but none of the variables of interest approach statistical significance.

The deviance statistics suggest that the models reported in Table 4 fit noticeably better than those of Table 3. Table 4 allows the coefficient on time (or the rate of technical progress) to vary across countries and looks at EQTEST and OPEN as potential sources of variation in the rate of technical progress. We find a pattern similar to that of Table 3: EQTEST and OPEN are both important, but their simultaneous inclusion reduces the estimated impact of EQTEST (although by less than on the education coefficients as reported in Table 3). The model with interaction between EQTEST and OPEN (model 22) does suggest, however, a statistically significant interaction in which EQTEST appears to be having an impact on the rate of technical progress principally in economically open countries. Model 22 allows evaluation of the effect of EQTEST in both fully open (OPEN = 1) and fully closed (OPEN = 0) economies, and its deviance statistic suggests it to be our best performing model. A one standard deviation (57 point) improvement in EQTEST in an open environment results in an increase of almost 
Table 4: Determinants of Income and of Country-Specific Estimates of the Rate of Technical Progress (51 countries, 255 observations, 1960-2000)

\begin{tabular}{ccccc}
\hline & \multicolumn{5}{c}{ Models } \\
\cline { 2 - 6 } Independent Variable & 19 & 20 & 21 & 22 \\
\hline \hline
\end{tabular}

I. Time-invariant determinants of income level:

Constant

TROPICAL

I. Time-varying determinants of income level:

LKPC

ED

LTFR

III. Determinants of technical progress:

Constant

EQTEST

OPEN

EQOPEN (interaction between EQTEST and OPEN)

$\begin{array}{rrrr}4.990 & 5.104 & 5.103 & 5.105 \\ (23.27) & (25.16) & (25.52) & (27.76) \\ -0.174 & -0.242 & -0.223 & -0.265 \\ (1.88) & (2.49) & (2.20) & (3.25)\end{array}$

-0.174
$(1.88)$

$\begin{array}{rrrr}0.350^{\mathrm{a}} & 0.350^{\mathrm{a}} & 0.350^{\mathrm{a}} & 0.350^{\mathrm{a}} \\ \mathrm{NA} & \mathrm{NA} & \mathrm{NA} & \mathrm{NA} \\ 0.070 & 0.058 & 0.056 & 0.055 \\ (4.04) & (3.96) & (3.73) & (4.16) \\ -0.092 & -0.112 & -0.108 & -0.096 \\ (1.18) & (1.29) & (1.33) & -(1.28)\end{array}$

$\begin{array}{llll}-0.020 & 0.001 & -0.007 & 0.028 \\ (2.35) & (0.32) & (0.92) & (2.62)\end{array}$

0.00006

$0.00002-0.00006$ (1.07) (2.61)

$\begin{array}{lll}0.012 & 0.011 & -0.064\end{array}$

(4.72) (3.59) (2.07)

0.00016

(2.57)

Model Statistics

Number of parameters estimated

10

10

11

12

Deviance $^{b}$

$-103.7$

$-116.9$

$-122.8$

a Coefficient on LKPC constrained to equal 0.35.

$\mathrm{b}$ "Deviance" is twice the negative log-likelihood value associated with the maximum likelihood parameter estimates. The larger the deviance, the poorer the fit.

Notes: 1 . The dependent variable is the logarithm of income per capita (LYPC).

2. t-values are shown in parenthesis below the estimated coefficients. 
0.6 percent per year in the rate of technical progress. (In comparison, from model 20 we see that increasing OPEN from 0 to 1 increases the rate of technical progress by 1.2 percent per year which suggests that improving test scores is significant on the scale of the powerful economic policy variable of openness.) In a closed economy the estimated impact of improved test scores is actually slightly negative, although very small.

Although many standard caveats apply to this analysis there are clear patterns in the results. First, our panel models point to results that are broadly consistent with the growth equations that Table 1 reports, including that improved education quality as measured by ISATs appears to have a quantitatively significant impact on growth. Second, the impact of quality appears to operate through affecting an economy's rate of technical progress rather than through affecting the returns to a year of education or through a static upward shift in the production function as a whole. And, third, the effects of both higher test scores and of additional years of education seem substantially greater in open than in closed economies.

\section{Education Quality and Decline in Infant Mortality}

Economists and others have been developing a body of research that, at least tentatively, assigns value to gains in health. One line of research assesses the instrumental value of better health in improving the earnings of individuals and the income levels and growth rates of nations. Methodologically the cross country element of that work relates directly to the approaches used in this paper - see, for example, Jamison, Lau and Wang (2005) and other chapters of the volume in which that paper appears. Jamison et al. conclude, among other things, that improved education levels and improved health conditions each account for perhaps 10-15 percent of economic growth in the later decades of the $20^{\text {th }}$ century.

A second line of economic analysis has attempted to quantify the intrinsic value of improvements in health. Countries' National Income and Product Accounts (NIPAs) include the value of inputs into health, e.g., pharmaceuticals and physician time, but place no value on mortality declines that might 
result. Bloom, Canning and Jamison (2004) provide an overview of evidence on both the instrumental and intrinsic value of changes in health and conclude that, where health conditions have been changing at a reasonable rate, inclusion of the value of health changes into a revised NIPA leads to substantial reinterpretation of the sources of change in national economic welfare. The intrinsic value of health improvements can easily be 3 to 5 times its instrumental value.

For these reasons studies of the determinants of growth in income per capita need to be complemented by equally comprehensive and rigorous studies of other components of change in economic welfare, of which mortality decline (or increase) may be the most quantitatively significant. This motivates our preliminary assessment of the impact of education quality on one dimension of mortality decline, the decline in the infant mortality rate (IMR). For most of the past half century the worldwide average rate of IMR decline has been on the order of 2 percent per year with variation from zero (or even negative) rates in some countries to annual rates as high as eight percent. Jamison, Sandbu and Wang (2004) assess education levels and other determinants of IMR decline and provide an introduction to the broader literature. This literature generally concludes that education levels (particularly of women) are likely to be important reasons for differences in IMR decline across countries.

Consideration of cross-country difference in IMR decline is, however, subject to the same challenges that have been raised to the growth modeling. Specifically, questions arise about whether the relationship between schooling levels and IMR decline is causal or not. As with growth modeling, investigations of health differences could be easily suffer from omitted variables. For example, higher income could lead to better health care and to purchasing more schooling. Or, better health and added life expectancy increases the returns to schooling, thus leading to more investment in schooling (see Grossman, 2005, for a fuller discussion). Likewise reduced child mortality is almost certainly associated with reduced morbidity and improved cognition and hence test scores in children. This may be particularly true for malaria in Africa, but the impact on this analysis would be limited since only 3 subSaharan African countries are included. These concerns are ameliorated but not eliminated by looking at changes in health status, as opposed to levels of health. Similarly, because of the substantial differences 
in the quality of each year of schooling across countries, large measurement problems are introduced. Moreover, these measurement errors could be directly related to other characteristics of countries that lead to better health.

These considerations suggest that variations in education quality may be appropriate for investigations of health outcomes and that they might be significant for explaining IMR decline just as they are significant for explaining economic growth. This section reports results based on the same panel data set analyzed in the previous section, and using closely analogous methods. (Appendix D provides a complementary analysis that predicts 40 year average rates of decline in IMR using methods similar to those used to generate the prediction of income growth rates reported in Table 1.)

\subsection{The Basic Model}

We model determinants of IMR levels with a framework that draws substantially on that of Jamison, Sandbu and Wang (2004) but that updates their data set and adds international student achievement test (ISAT) data, i.e. the variable EQTEST. Equation 6 is the basic model:

(6) $\mathbf{L I M R}_{\mathrm{it}}=\alpha_{0 \mathrm{i}}+\alpha_{1 \mathrm{i}} \mathbf{T I M E}_{\mathrm{t}}+\alpha_{2 \mathrm{i}} \mathbf{E D}_{\mathrm{it}}+\alpha_{3} \mathbf{L Y P C}_{\mathrm{it}}+\varepsilon_{\mathrm{it}}$.

The variables are as defined for equation (1) and the coefficients are defined as follows:

$\alpha_{0 \mathrm{i}}$ : the country-specific intercept for country $i$;

$\alpha_{1 \mathrm{i}}$ : the effect of 'technical progress' in decreasing IMR in country $i$;

$\alpha_{2 \mathrm{i}}$ : the impact on IMR of education in country $i$;

$\alpha_{3}$ : the effect on IMR of income per capita ; and

$\varepsilon_{\text {it }}$ : the unexplained residual for country $i$ at time $t$, assumed to be normally distributed with mean 0 . 
Equations (7) and (8) (analogous to equations (3) and (4)) use the specification from Jamison, Sandbu and Wang (2004) - with the addition of EQTEST - to explain country specific intercepts and technical progress:

(7) $\alpha_{0 \mathrm{i}}=\delta_{00}+\delta_{01}$ TROPICAL $_{\mathrm{i}}+\mu_{0 \mathrm{i}}$, and

(8) $\alpha_{1 \mathrm{i}}=\delta_{10}+\delta_{11} \mathbf{E Q T E S T}_{\mathrm{i}}+\delta_{12} \mathbf{O P E N}_{\mathrm{i}}+\mu_{1 \mathrm{i}}$

\subsection{Statistical Results}

Table 5 reports our results on the determinants of IMR. Model 23 shows our results when both the coefficient on time and the coefficient on education are constrained to be the same across all countries (i.e., $\alpha_{1 \mathrm{i}}=\alpha_{1 \mathrm{j}}$ and $\alpha_{2 \mathrm{i}}=\alpha_{2 \mathrm{j}}$ for all $\mathrm{i}$, $\mathrm{j}$, although $\alpha_{0 \mathrm{i}}$ is not constrained to equal $\alpha_{0 \mathrm{j}}$ ). This is a basic model in the literature (e.g. Pritchett and Summers, 1996) and its estimated income elasticity of IMR at -0.38 is typical. Models 24 and 25 relax, respectively, the constraint that the coefficient on education and the coefficient on time are constant across countries. The deviance statistics indicate that both of these changes, particularly in model 25, improve model fit. Consistent with previous findings of Jamison, Sandbu and Wang, the improved specification of model 25 results in a substantial reduction in the

estimated impact of income on IMR. Improved model specifications and more comprehensive analyses e.g. Cutler, Deaton and Lleras-Muney (2006) - increasingly point to a relatively minor role for income levels in influencing health outcomes.

Similar to Model 13 in Table 2, model 24 provides country-specific estimates of the coefficient on education, in this case of education on IMR. Although the estimated effects of education on IMR are correlated strongly with education's effect on income (-0.32), there are many countries where the effects differ. In China, for example, an additional year of education is estimated to increase income by 15.9 percent, almost twice the average, whereas a year of education reduces IMR by only 6 percent, less than 
Table 5: Determinants of Infant Mortality Rates

(51 countries, 255 observations, 1960-2000)

\begin{tabular}{|c|c|c|c|c|c|c|}
\hline \multirow[b]{2}{*}{ Independent Variable } & \multicolumn{6}{|c|}{ Models } \\
\hline & 23 & 24 & 25 & 26 & 27 & 28 \\
\hline \multicolumn{7}{|c|}{ I. Time-invariant determinants of IMR level: } \\
\hline Constant & $\begin{array}{r}7.878 \\
(12.87)\end{array}$ & $\begin{array}{r}6.610 \\
(10.57)\end{array}$ & $\begin{array}{r}6.019 \\
(11.47)\end{array}$ & $\begin{array}{r}6.073 \\
(11.22)\end{array}$ & $\begin{array}{r}6.282 \\
(13.94)\end{array}$ & $\begin{array}{r}6.220 \\
(12.34)\end{array}$ \\
\hline TROPICAL & $\begin{array}{l}0.118 \\
(0.70)\end{array}$ & $\begin{array}{l}0.222 \\
(1.30)\end{array}$ & $\begin{array}{l}0.154 \\
(1.01)\end{array}$ & $\begin{array}{l}0.232 \\
(1.46)\end{array}$ & $\begin{array}{l}0.126 \\
(0.94)\end{array}$ & $\begin{array}{l}0.149 \\
(1.11)\end{array}$ \\
\hline
\end{tabular}

II. Time-varying determinants of income level:

\begin{tabular}{|c|c|c|c|c|c|c|c|}
\hline LYPC & & $\begin{array}{r}-0.377 \\
(4.91)\end{array}$ & $\begin{array}{r}-0.209 \\
(2.70)\end{array}$ & $\begin{array}{r}-0.146 \\
(2.13)\end{array}$ & $\begin{array}{l}-0.156 \\
(2.22)\end{array}$ & $\begin{array}{r}-0.174 \\
(2.85)\end{array}$ & $\begin{array}{r}-0.173 \\
(2.61)\end{array}$ \\
\hline ED & & $\begin{array}{r}-0.130 \\
(6.37)\end{array}$ & & $\begin{array}{r}-0.141 \\
(6.81)\end{array}$ & $\begin{array}{r}-0.141 \\
(7.24)\end{array}$ & $\begin{array}{r}-0.145 \\
(7.45)\end{array}$ & $\begin{array}{r}-0.137 \\
(7.63)\end{array}$ \\
\hline ED & $\begin{array}{l}\text { (average of country-specific } \\
\text { estimates) }\end{array}$ & & $\begin{array}{r}-0.139 \\
(6.06)\end{array}$ & & & & \\
\hline TIME & & $\begin{array}{r}-0.018 \\
(7.81)\end{array}$ & $\begin{array}{r}-0.021 \\
(8.18)\end{array}$ & & & & \\
\hline TIME & $\begin{array}{l}\text { (average of country-specific } \\
\text { estimates) }\end{array}$ & & & $\begin{array}{r}-0.023 \\
(10.07)\end{array}$ & & & \\
\hline
\end{tabular}

III. Determinants of technical progress in IMR:

Constant

$\begin{array}{rrr}-0.011 & 0.041 & 0.037 \\ (4.42) & (3.31) & (2.92) \\ & -0.00013 & -0.00011 \\ & (5.18) & (3.87) \\ -0.018 & & -0.013 \\ (4.98) & & (2.92)\end{array}$

$\underline{\text { Model Statistics }}$

Number of parameters estimated

\begin{tabular}{ccrrrr}
7 & 9 & 9 & 10 & 10 & 11 \\
44.4 & -16.7 & -45.4 & -59.1 & -63.6 & -72.4 \\
\hline
\end{tabular}

a "Deviance" is twice the negative log-likelihood value associated with the maximum likelihood parameter estimates. The larger the deviance, the poorer the fit.

Notes: $\quad 1$. The dependent variable is the logarithm of the infant mortality rate (deaths in the year following birth per 1000 live births)

2. $\mathrm{t}$-values are shown in parenthesis below the estimated coefficients. 
half the average. Appendix Table C2 reports estimates of education's effect on IMR in each country for which we have data.

Models 26 to 28 build on our model 24 by continuing to allow the coefficient on time to be country-specific but, additionally, by exploring the determinants of the time coefficient (equation 8). Both OPEN and EQTEST significantly affect the time coefficient whether entered individually (models 26 and 27) or together (model 28). From model 28 the estimated impact of a one standard deviation (57 point) improvement in test scores is quantitatively important: it would change the annual rate of decline by -0.6 percent, i.e. by about 25 percent of the coefficient on time from model 25 . A country starting with any given IMR in 1960 would see it decline to 79 percent of whatever it would otherwise have declined to by 2000 if EQTEST were improved by one standard deviation. Preston and Haines (1991) used US census data from around the beginning of the $20^{\text {th }}$ century to argue that the value of education for improving health appeared to be nil prior to the emergence of specific scientific knowledge and related means for improving health. Today, a rich variety of means exist for reducing IMR and it appears, unsurprisingly, that higher levels of cognitive skill facilitate the uptake and utilization of available knowledge and methods.

While we do not explicitly address the issues of endogeneity of cognitive skills, we believe that the various tests applied in the economic growth modeling create a strong presumption that these concerns are not serious. We thus believe that the preliminary decline analysis for IMR suggests an additional and extremely important element supporting improved education policies.

\section{Conclusions}

The results from Sections 3 and 4 support the existence of a link between educational quality and economic outcomes such as income per capita. ISATs in mathematics appear to be measuring an element of human capital that is important to growth in income per capita and that is not captured by quantity (years) of schooling on its own. This effect is quantitatively important: depending on the specific assumptions, a one standard deviation increase in test scores is associated with an increase in annual 
growth in income per capita of 0.5-0.9 percent (with our preferred model at the low end of the range). We do not, however, find statistically significant support for using a quality measure based on US labor market returns to schooling in different countries as a measure of human capital (Bratsberg and Terrell, 2002) to explain economic output.

Among the three mechanisms that we explore for why test scores are important (impact on the level of output, impact on the rate of technical progress, or impact on the size of the increment to output caused by an increase in a country's average quantity of education), we find the strongest support for the idea that quality impacts economic output through changes in the rate of technical progress. This is supported by our panel data models of the level of economic output and is also consistent with the findings from our growth rate models. These findings of the economic impact of improved cognitive ability at a country-wide level complement and extend similar findings at the individual level (Knight and Sabot (1990) for Kenya and Tanzania), Behrman and Birdsall (1983) for Brazil, or at the small farm level (Jamison and Moock (1984) for Nepal). Hanushek (2005a, b) summarizes other international studies and highlights the similarity of separate findings for the U.S. by Mulligan (1999), Lazear (2003), and Murnane, Willett, Duhaldeborde, and Tyler (2000).

While more comprehensive investigations are warranted, we find (in section 5) a strong association between education quality and declines in IMR. Coincidentally the quantitative effect has about the same absolute value as the effect on income: a one standard deviation increase in test scores is estimated to increase the annual rate of decline in IMR by 0.6 percent. The importance of health improvements to overall gains in welfare suggests that this should be a high priority are for future investigation.

In our more detailed exploration of the determinants of cross country variation in rates of technical progress in both income growth and mortality decline we find that the impact of cognitive skills depends importantly on openness of the economy. This supports the idea that education, in our case education quality in particular, improves productivity most significantly in an economic environment that is open to outside trade and influence. In fact, our analysis taken literally suggests that higher test scores 
are associated with higher rates of technical progress only in open economies. This result can be seen as a macroeconomic analog to Shultz’s (1993) finding that education is most important in modernizing, as opposed to static, environments. This finding is also consistent with recent discussions of education and growth that emphasize the importance of complementary institutions (Easterly 2002, Pritchett 2006 forthcoming). Also, as discussed in Section 5, Preston and Haines (1991) find that education only reduces mortality rates if the proper external conditions exist; these can be seen as analogous findings.

Returning to the impact of education quality, as measured by ISATs, on the growth of income per capita, it is natural to ask how policy changes designed to improve education quality should be evaluated as a mechanism to improve growth rates. There is an extensive literature on the impacts of various interventions on test scores. One list of such interventions, compiled with a focus on developing countries, can be found in Lockheed and Hanushek (1988); Jamison and Radelet (2005) provide a briefer summary that emphasizes exposure to schooling. A complementary view is that devising plans to improve teacher quality could yield the kinds of improvements that are needed (Hanushek 2005a).

Many plausible ways to improve test scores compare favorably in terms of cost to increasing years of schooling. To take an example, the Philippines in the course of the late 1980s decreased the ratio of students to textbooks in key elementary school subjects from 10:1 to 2:1 at an increase in per student costs of about 1 percent. An evaluation of the impact on student test scores estimated increases of 0.18 to 0.51 standard deviations in the distribution of test scores, depending on grade and subject, after one year (Heyneman, Jamison and Montenegro, 1984). (If these results were put in terms of the cross country test score distribution, they would be about 50 percent larger.) It would be conservative to extrapolate, although still very much an extrapolation, that after 10 years the cumulative improvement would be at least one standard deviation of the cross country distribution at a cost per student equal to 10 percent of the cost of a year of schooling. The estimated effect would be to increase both income growth rates and IMR decline rates by roughly 0.5 percent per year or, after 20 years, to result in a 10 percent improvement in income of mortality levels. A full year's increase in schooling (at 10 times the cost) might increase income by 5-7 percent or decrease IMR by 13 percent. While this calculation can only be considered 
very rough and preliminary, it does suggest, over a broad range of reasonable parameter estimates, that the economic and health effects of appropriate quality investments can well exceed those from increasing the average number of years of schooling. 


\section{Appendix A: Variable Definitions and Descriptive Statistics}

Appendix Table A.1 provides definitions and sources for all the variables used in our analysis. YPC and the investment ratio are from Penn World Tables 6.1 (Heston, Summers and Aten 2002). KPC is calculated from these two variables using a perpetual inventory approach. TFR comes from the 2002 World Development Indicators (World Bank, 2002). ED comes from a data set created by Cohen and Soto (2001), supplemented by the Barro and Lee (2001) data set; this is explained more fully in Appendix B where we also provide the values of ED that we use for each country and year. These values are the average years of education among the population aged 15 -64. EQTEST is constructed by combining results from a series of international mathematics tests administered over the past 40 years; details on how our country specific measures were constructed are found in the next section and developed further in Appendix B. EQBT comes from Bratsberg and Terrell (2002). It is the labor market return (in the US) to a year of education (in the home country) for immigrants to the US. EQBT is calculated separately for each country with a large enough sample of immigrants, and we use a simple average of the two reported values for the years 1980 and 1990. OPEN and TROPICAL come from the Harvard Center for International Development. OPEN is equal to the fraction of years between 1960 and 1998 that the country in question was classified as having an economy open to international trade.

Tables A.2a and A.2b provide descriptive statistics for the variables that we use that are fixed for a given country over the 1960-2000 time period we consider, for example the variable TROPICAL indicating how much of a country lies with the geographic tropics. We include variables in this table that are averages for the time period and that are growth rates over it. For convenience, we also include the 1960 values of those variables that vary with time over the period that we use in the growth regressions. Appendix Table A.3 provides descriptive statistics for the variables that vary over time that are used in our panel analyses.

The variable OPEN captures directly the impacts of having an economy that is open to trade and competition and free from other major distortions. However, it is likely that is also serves as a proxy for

broader characteristics that are often described as "institutional quality”. Institutional quality has received 
much attention recently as a determinant of economic performance; for example see Easterly and Levine (2003). As a result, we explored the possibility that OPEN is not sufficiently controlling for institutional quality and that this might be resulting in an upward bias to our estimated coefficient on EQTEST in model 6. Specifically, we estimated alternate versions of model 6 with the additional variable INST. This variable is the average of the six institutional quality measures that are derived in Kaufmann, Kraay and Zoido-Lobaton (1999). Those six measures are aggregated from multiple sources and represent one of the most comprehensive efforts to measure institutional quality. We find that the addition of INST to model 6, either in addition to or instead of OPEN, does not significantly change the coefficient on EQTEST. In addition we explored the addition of a variable (GLOBAL) that is a measure of a country's economic social and political globalization (Dreher, 2006). Use of GLOBAL results in no significant change in our results. We also considered the use of the recently released World Bank Country Policy and Institutional Assessment (CPIA) rating. This is intended to capture the quality of a country's policies and institutional arrangements based on the judgment of World Bank staff. While potentially valuable, this indicator is available only for developing countries and therefore could not be used for our analysis where the sample also includes many developed countries. 


\section{Appendix B: Origins and Country Specific Values of the Education and Education Quality Variables}

This Appendix provides documentation on the education-related variables used in our analyses - first on years of schooling, second on returns in the US labor market and, finally, test scores.

$\underline{\text { Years of Education }}$

A number of prior studies relating education to economic output have used educational attainment time series from Robert Barro and Jong-Wha Lee. The most recent version of this data is found in Barro and Lee (2001) which contains data at five year intervals from 1960 to 2000 for up to 142 countries, 109 countries have complete information. The year 2000 values in this data series are projections.

An alternative data series on educational attainment has been constructed by Daniel Cohen and Marcelo Soto at the OECD Development Center. This data set provides estimates of the average years of education among the adult population for 95 countries every 10 years from 1960 to 2000. We have chosen to use the Cohen-Soto data as our primary data series. Their data are more recent and do not involve projections for 2000. In addition, Cohen and Soto (2001) identify explicitly a number of the factors that result in differences between their data set and the Barro-Lee data set and what improvements and fixes they have attempted to make.

For all countries for which data are available from Cohen-Soto, we use their estimate of average years of education completed among the population (male and female) between the ages of 15 and 64 as our value of ED. For countries without data from Cohen-Soto but with data from Barro-Lee, we estimate ED based on the observed relationship between the Cohen-Soto values and the Barro-Lee values in countries for which we have data from both sources. Specifically, we estimate the following equation:

$$
\text { EDCS }_{\mathrm{it}}=\alpha_{0}+\alpha_{1} \text { EDBL }_{\mathrm{it}}+\alpha_{\mathrm{x}} \text { (vector of indicator variables for each year) }+\varepsilon_{\mathrm{it}}
$$

\footnotetext{
* Both Krueger and Lindahl (2001) and Cohen and Soto (2001) present evidence regarding potentially significant measurement error within the Barro-Lee time series.
} 
We use the estimated coefficients from this equation to calculate predicted values of EDCS (the CohenSoto educational attainment measure) and use those predicted values to fill in values for ED that otherwise would have been missing. ${ }^{\dagger}$ As shown in Table B.1, this adds 8 countries to our dataset.

\section{Education quality measured by returns in the US labor market}

Bratsberg and Terrell (2002) analyze, using data from the 1980 and 1990 US Censuses the earnings of immigrants in the US labor market using standard formulations that control for education, experience and other factors. The innovative element of their analysis is that they also examine the country in which the immigrant received his or her education and calculate a separate return to education for each country from which there are a sufficient number of immigrants. In doing so they control for English language ability so the varying country returns are not picking up differential language skills. Bratsberg and Terrell suggest that one interpretation of the varying country returns is that they reflect variations in the quality of education in each country; it is this interpretation that we adopt here. Table B.2 shows the returns to education by country as given in Bratsberg and Terrell (2002).

Education quality measured by international student achievement tests (ISATs)

A key element of our work is developing a measure of cognitive skills that can equate workers across countries on the basis of their quality. Past work (Hanushek and Kimko, 2000; Barro 2000) has pointed to the value of using measures of cognitive ability from international tests to identify important differences. Nonetheless, the previous measures have been based upon a relatively small number of countries and have not confronted the problems of combining different test instruments into a composite measure.

This analysis relies on the international test metrics developed by Hanushek and Wößmann (in process). The key is using outside information on test performance over time to calibrate the observed

\footnotetext{
${ }^{\dagger}$ In order to assess whether the values for ED that are predicted from Barro-Lee data are behaving differently from the rest of our data we ran a simple imputation test. We estimated a basic growth regression including indicator variables for imputed values but found that they were not statistically significant.
} 
international performance data. For this paper, we use the mathematics portion of the international tests calibrated by Hanushek and Wößmann.

International assessments of student achievement, aimed largely at mathematics and science, were begun over four decades ago. Although national participation has been voluntary, recent expansions to all OECD countries, and to other countries, have led to increasingly valid and reliable indicators of qualitative differences in human capital. Internationally comparable student achievement tests began with the First International Mathematics Study (FIMS), which tested in 1964. The latest international studies for which data are available are the Trends in International Mathematics and Science Study (TIMSS) ${ }^{\ddagger}$ and the Programme for International Student Assessment (PISA), both conducted in 2003. From FIMS to the latest TIMSS and PISA, a total of 14 international student achievement tests (ISATs) were conducted. Although varying across the individual assessments, testing covers mathematics, science and reading for three age/grade groups: primary education (age 9 or 10), lower secondary education (age 13 to 15), and the final year of secondary education (which is generally grade 12 or 13).

Our analysis here relies exclusively on the international mathematics comparisons. This reflects past analyses that show mathematics performance to be particularly important in describing individual variations in earnings. It also reflects a sense that developing valid and reliable international assessments is easier in the case of mathematics than language or science.

A total of 72 countries have participated in at least one of the ISATs, but several of the countries have participated at only one or a few points in time. Even within the same assessment, countries do not always participate at all grade levels. The largest number of countries tends to have participated at the lower secondary level.

A major drawback in comparative uses of the various ISATs is that the scales of their test-score results are not directly equated across tests. They do not use the same test questions; nor do they even use the same technique and scale of mapping answers into test scores.

\footnotetext{
‡ TIMSS was previously an acronym for the Third International Mathematics and Science Study when the IEA did testing in 1995.
} 
Hanushek and Wößmann (in process) have developed a common metric both for the level of test performance on the ISATs and for the variation of test performance on the ISATs.

Comparable level. The National Assessment of Educational Progress (NAEP) in the United States tests the mathematics, science and reading performance of nationally representative samples of 9-, 13- and 17-year-old US students in an intertemporally comparable way since 1969. They calculate the US performance difference in mathematics between 1999 and any earlier point in time and express it in standard deviations of the international PISA study, which was conducted in 2000. This alone does not, however, yet yield a common scale for all the countries on the different tests, because it is necessary to determine "how much" above or below.

Comparable variation. To develop a common variance, Hanushek and Wößmann (in process) look to the stable group of OECD countries that had high levels of secondary school completion since the first international testing. There are 13 countries that they consider the “OECD Standardization Group” (OSG) of countries: Austria, Belgium, Canada, Denmark, France, Germany, Iceland, Japan, Norway, Sweden, Switzerland, the United Kingdom and the United States. By assuming that the cross-country variation in educational performance among the OSG countries did not vary substantially since 1964, they can use the OSG countries to develop a comparable scale for the variation on the different ISATs.

The final element of the calculation is to average the calibrated mathematics scores across all of the observations for each country. Doing this represents a compromise. The basic objective is not to measure quality of students but to obtain an index of the quality of the workers in a country. If the schools and skills of graduates are constant over time, this averaging is appropriate and uses the available information to obtain the most reliable estimate of quality. If on the other hand there is changing performance, this averaging will introduce measurement error of varying degrees over the sample of economic data (1960-2000). The analysis in Hanushek and Wößmann (in process) shows some variation over time, but there is no clear way to deal with this here. 


\section{Appendix C: Country Specific Estimates of the Effects of Education on Income and Infant Mortality}

The HLM analyses reported in Sections 4 and 5 of this paper allow calculation of estimates of the country specific impact of education on income (from Table 2, model 13) and on IMR (from Table 5, model 24). Table $\mathrm{C} 1$ shows these estimates for income and compares them to recent estimates, by country, of individual education levels on income. Estimates of returns to education at the country level bear little relation to individual level (or private) returns; indeed the correlation is only 0.03 . We attribute this to substantial labor market imperfections, particularly in developing countries.

Appendix Table C2 shows our country-specific estimates of the effect of education on IMR. The correlation between the country-specific coefficients of education on income and on IMR is -0.318 , that is, in countries where education has a stronger favorable impact on income it is likely to have a stronger favorable (i.e. negative) impact on IMR. 


\section{Appendix D: Determinants of Decline in Infant Mortality Rates}

This appendix reports estimates of the determinants of the rate of decline in IMR that parallel the assessments of the determinants of economic growth rates reported in the main text (Table 1). The dependent variable in the "decline" regressions is the rate of IMR reduction in percent per year. We follow the structure of the growth regressions reported in Table 1 as closely as possible to underline the parallel nature of the analyses.

Models 29-31 in Appendix Table D1 use initial levels of income and IMR as factors explaining the rate of IMR decline, while models 32-34 use the natural logarithms of these variables. Further research will be needed to select among specifications, but for our purposes, two conclusions remain robust to specification:

(i) Our measure of country performance on mathematics tests (EQTEST) has predictive power while initial education levels do not.

(ii) When we include economic openness (OPEN) in the specification, the value of the coefficient on EQTEST declines but nonetheless remains important. In our preferred model 34, EQTEST's effect is quantitatively highly important: a one standard deviation test score improvement (57 points) would lead to an increase of about 0.75 percent per year in the rate of IMR decline even controlling for OPEN. In the analogous model 31 (where key independent variables are logged) the effect would be about half as large. Estimates of effect size may be sensitive not only to, as we have observed, details of specification but also to whether we are using male, female, or combined education levels and test scores and to the length of the time horizon.

We view these findings as suggestive but far from definitive on the importance of improved cognition for effecting mortality change. 


\section{References}

Barro, Robert J. 2001. "Human Capital and Growth." American Economic Review 91,no.2 (May):12-17.

Barro, Robert J. Determinants of Economic Growth. (Cambridge, MA: The MIT Press, 1997).

Barro, Robert J., and Xavier Sala-i-Martin, 2003, Economic Growth, 2nd Edition (Cambridge, Massachusetts: MIT Press).

Barro, Robert J., and Jong-wha Lee. 2001. "International Data on Educational Attainment: Updates and Implications." Oxford Economic Papers 53,no.3 (July):541-563.

Behrman, Jere R. and Nancy Birdsall. 1983. “The Quality of Schooling: Quantity Alone is Misleading,” American Economic Review, Vol 73, no. 5, pp. 928-46.

Bils, Mark, and Peter J. Klenow, 2000, “Does Schooling Cause Growth?” American Economic Review, Vol. 90, No. 5 (December), pp. 1160-83.

Bloom, D. E., Canning, D. and Jamison, D.T. “Health, Wealth and Welfare.” Finance \& Development, 41 (March 2004), 10-15.

Bloom, David E. and Williamson, Jeffrey G. "Demographic Transitions and Economic Miracles in Emerging Asia.” The World Bank Economic Review, 12 (1998), 419-455.

Boskin, M. J. and Lau, L. J. "Post-war Economic Growth in the Group-of-Five Countries: A New Analysis.” Stanford University: Department of Economics, April 1992.

Bratsberg, Bernt and Dek Terrell. "School Quality and Returns to Education of US Immigrants.” Economic Inquiry, April 2002, 40(2), pp. 177-198.

Cohen, Daniel and Soto, Marcelo. “Growth and human capital: Good data, good results.” OCED Development Center Technical Paper \#179, September 2001.

Cutler, David, Angus Deaton and Adriana Lleras-Muney. 2006. “The Determinants of Mortality.” Journal of Economic Perspectives, Vol. 20 (no. 3, summer): 97-120.

Dreher, Axel (2006): “Does Globalization Affect Growth? Evidence from a new Index of Globalization”, Applied Economics 38, 10: 1091-1110.

Easterly, W. The Elusive Quest for Growth. (Cambridge, MA: The MIT Press, 2001).

Easterly, William and Ross Levine. "Tropics, germs, and crops: How endowments influence economic development.” Journal of Monetary Economics. Amsterdam: Jan 2003. Vol. 50, Issue 1; pg. 3.

Grossman, Michael. 2005. "Education and Nonmarket Outcomes”. National Bureau of Economic Research, Working Paper 11582.

Hall, R. E. and C. I. Jones. "Levels of Economic Activity Across Countries.” American Economic Review (Papers and Proceedings), 1997, 87: 173-177.

Hanushek, Eric A., 1995, “Interpreting Recent Research on Schooling in Developing Countries,” World Bank Research Observer, Vol. 10, No. 2, pp. 227-46.

_ 2003, “The Failure of Input-based Schooling Policies,” Economic Journal, 113 (February), pp. F64-F98.

Hanushek, Eric A. 2005(a). "The Economics of School Quality." German Economic Review 6,no.3

(August):269-286. 
Hanushek, Eric A. 2005(b). "Why Quality Matters in Education,” Finance and Development, v. 42, pp. 15-19.

Hanushek, Eric A. and Dennis D. Kimko. "Schooling, Labor-Force Quality, and the Growth of Nations." American Economic Review, December 2000, 90(5), pp. 1184-1208.

Hanushek,. Eric A. and Ludger Wößmann (in process), The Human Capital of Nations (Munich: CESifo).

Heston, Alan, Robert Summers and Bettina Aten, Penn World Table Version 6.1, Center for International Comparisons at the University of Pennsylvania (CICUP), October 2002.

Heyneman, Stephen P., Dean T. Jamison and Xenia Montenegro. 1984. "Textbooks in the Philippines: Evaluation of the Pedagogic Impacts of a Nationwide Investment.” Educational Evaluation and Policy Analysis, vol. 6, no. 2, pp. 139-150.

Islam, Nazrul. “Growth empirics: a panel data approach.” Quarterly Journal of Economics, CX (1995), 1127-1170.

Jamison, Dean T., Lawrence J. Lau and Jia Wang. "Health’s Contribution to Economic Growth in an Environment of Partially Endogenous Technical Progress.” In G. Lopez-Casasnovas, B. Rivera and L. Currais (eds.), Health and Economic Growth: Findings and Policy Implications. Cambridge, MA: MIT Press, 2005. Pp. 67-91.

Jamison, D. T. and S. Radelet. "Making Aid Smarter,” Finance and Development, v. 42: 2, June 2005, pp. 42-46.

Jamison, D. T. , M. E. Sandbu and J. Wang. "Why has Infant Mortality Declined at such Different Rates in Different Countries?” Available as Working Paper No. 21 of the Disease Control Priorities Project.

Jamison, D.T. and Peter Moock. Farmer Education and Farm Efficiency in Nepal: the Role of Schooling, Extension services and Cognitive skills. World Development, 1984, 12, 67-86.

Kaufmann, Daniel, Aart Kraay and Pablo Zoido-Lobaton (1999). "Aggregating Governance Indicators". World Bank Policy Research Department Working Paper No. 2195.

Knight, John B., and Richard H. Sabot. 1990. Education, Productivity, and Inequality: The East African Natural Experiment. 1990: Oxford University Press..

Kreft, Ita and Jan de Leeuw. Introducing Multilevel Modeling. (London: Sage Publications, 1998.)

Krueger, Alan B. and Mikael Lindahl. “Education for Growth, Why and For Whom?” Journal of Economic Literature, December 2001, vol. 39, pp. 1101-1136.

Lazear, Edward P. 2003. "Teacher incentives." Swedish Economic Policy Review 10,no.3:179-214.

Lee, Kevin, Pesaran, M. Hashem and Smith, Ron. "Growth and Convergence in a Multi-country Empirical Stochastic Growth Model”. Journal of Applied Econometrics, 12 (1997), 357-392.

Lee, Kevin, Pesaran, M. Hashem and Smith, Ron. "Growth Empirics: a Panel Data Approach - a Comment.” Quarterly Journal of Economics, CXIII (1998), 319-323.

Lockheed, Marlaine E. and Eric Hanushek. 1988. "Improving Educational Efficiency in Developing Countries: What Do We Know?” Change, vol. 18, no. 1, pp 21-38.

McMahon, W. W. 2003. Education and Development: Measuring the Social Benefits. New York and Oxford: Oxford University Press.

Mulligan, Casey B. 1999. "Galton versus the Human Capital Approach to Inheritance." Journal of Political Economy 107,no.6, pt. 2 (December):S184-S224. 
Murnane, Richard J., John B. Willett, Yves Duhaldeborde, and John H. Tyler. 2000. "How Important are the Cognitive Skills of Teenagers in Predicting Subsequent Earnings?" Journal of Policy Analysis and Management 19,no.4 (Fall):547-568.

National Assessment of Educational Progress. 2005. The nation's report card, 08 September 20052005 [cited September 2005]. Available from http://nces.ed.gov/nationsreportcard/

Or, Z., Jia Wang and Dean Jamison. "International Differences in the Impact of Doctors on Health: a Multilevel Analysis of OECD Countries.” Journal of Health Economics, v. 24(3), 2005, 531-560.

Preston, S. H., and M. Haines. 1991. Fatal Years: Child Mortality in Late 19th Century America. Princeton, NJ: Princeton University Press.

Pritchett, Lant, 2001, “Where Has All the Education Gone?” World Bank Economic Review, Vol. 15, No. 3, pp. 367-91.

Pritchett, Lant. 2006 forthcoming. "Does Learning to Add Up Add Up? The returns to schooling in aggregate data." In Handbook on the Economics of Education, edited by Eric A. Hanushek and Finis Welch. Amsterdam: Elsevier.

Pritchett, Lant and Lawrence H. Summers. 1996. "Wealthier is Healthier”. Journal of Human Resources, 31:4, pp. 841-68.

Psacharopoulos, George and Harry A. Patrinos. "Returns to Investment in Education, A Further Update.” Draft (undated), The World Bank.

Raudenbusch, Steven, Bryk, Anthony, Cheong, Yuk F., and Congdon, Richard. HLM5: Hierarchical Linear and Nonlinear Modeling. (Lincolnwood, IL: Scientific Software International, Inc, 1999).

Rivkin, Steven G., Eric A. Hanushek, and John F. Kain, 2005, “Teachers, Schools, and Academic Achievement,” Econometrica, Vol. 73, No. 2 (March), pp. 417-58.

Sachs, J. and Warner, A. "Fundamental Sources of Long-run Growth.” American Economic Review (Papers and Proceedings) 87 (1997a), 184-188.

Sachs, Jeffrey D. and Andrew M. Warner, “Sources of Slow Growth in African Economies”, Journal of African Economies, December 1997b, Volume 6, Number 3, pp.335-376.

Schultz, T.P. Origins of Increasing Returns. (Oxford: Blackwell, 1993).

Temple, J. “The new growth evidence.” Journal of Economic Perspectives, 37 (1999), 112-156.

Topel, Robert, 1999, “Labor Markets and Economic Growth,” in Handbook of Labor Economics, edited by Orley Ashenfelter and David Card (Amsterdam: Elsevier), pp. 2943-84.

World Bank. World Development Indicators. Washington, DC: The World Bank, 2002. 
Table A.1 Variable Definitions and Sources

\begin{tabular}{|c|c|c|}
\hline Variable & Definition & Source \\
\hline $\mathrm{YPC}_{\mathrm{i}, \mathrm{t}}$ & $\begin{array}{l}\text { Per capita income (PPP adjusted) in } \\
\text { country i at time } t\end{array}$ & Penn World Tables 6.1 \\
\hline $\operatorname{LYPC}_{i, t}$ & Natural logarithm of $\mathrm{YPC}_{\mathrm{i}, \mathrm{t}}$ & Calculated \\
\hline YPC60 $_{\mathrm{i}}$ & 1960 value of $\mathrm{YPC}_{\mathrm{i}, \mathrm{t}}$ divided by 1000 & Calculated \\
\hline LYPC60 $_{i}$ & Natural logarithm of 1960 value of $\mathrm{YPC}_{\mathrm{i}, \mathrm{t}}$ & Calculated \\
\hline YPCGR $_{\mathrm{i}}$ & $\begin{array}{l}\text { Average annual growth rate of } \mathrm{YPC}_{\mathrm{i}, \mathrm{f}} \text { from } \\
1960 \text { to } 2000 \text {, expressed as a percentage } \\
\text { (decimal value multiplied by } 100 \text { ) }\end{array}$ & Calculated \\
\hline $\mathrm{KPC}_{\mathrm{i}, \mathrm{t}}$ & $\begin{array}{l}\text { Estimated physical capital stock in country } \\
\text { i at time t }\end{array}$ & $\begin{array}{l}\text { Calculated using perpetual inventory } \\
\text { method from YPC and each country's } \\
\text { yearly investment rates (from Penn World } \\
\text { Tables 6.1) }\end{array}$ \\
\hline $\operatorname{LKPC}_{i, t}$ & Natural logarithm of $\mathrm{KPC}_{\mathrm{i}, \mathrm{t}}$ & Calculated \\
\hline LYMK $_{\mathrm{i}, \mathrm{t}}$ & $\mathrm{LYPC}_{\mathrm{i}, \mathrm{t}}-0.35 * \mathrm{LKPC}_{\mathrm{i}, \mathrm{t}}$ & Calculated \\
\hline$E D_{i, t}$ & $\begin{array}{l}\text { Average years of education among the } \\
\text { population between the ages of } 15 \text { and } 64 \\
\text { in country } i \text { at time } t\end{array}$ & $\begin{array}{l}\text { Cohen and Soto (2001), missing data filled } \\
\text { in using an estimated value based on } \\
\text { years of schooling from Barro and Lee } \\
(2000)\end{array}$ \\
\hline $\mathrm{ED60}_{\mathrm{i}}$ & 1960 value of $E D_{i, t}$ & Calculated \\
\hline $\mathrm{TFR}_{\mathrm{i}, \mathrm{t}}$ & $\begin{array}{l}\text { Total fertility rate of the population in } \\
\text { country i at time } t\end{array}$ & $\begin{array}{l}\text { World Bank, World Development } \\
\text { Indicators } 2002\end{array}$ \\
\hline LTFR $_{\mathrm{i}, \mathrm{t}}$ & Natural logarithm of $\mathrm{TFR}_{\mathrm{i}, \mathrm{t}}$ & Calculated \\
\hline TFRAVG $_{i}$ & $\begin{array}{l}\text { Average of } T F R_{i, t} \text { for country } i \text { across all } \\
\text { five time periods }(1960-2000)\end{array}$ & Calculated \\
\hline $\mathrm{IMR}_{\mathrm{i}, \mathrm{t}}$ & $\begin{array}{l}\text { Infant mortality rate in country i at time t, } \\
\text { expressed as deaths within one year per } \\
1000 \text { live births }\end{array}$ & $\begin{array}{l}\text { World Bank, World Development } \\
\text { Indicators } 2002\end{array}$ \\
\hline $\operatorname{LIMR}_{\mathrm{i}, \mathrm{t}}$ & Natural logarithm of IMR $\mathrm{I}_{\mathrm{i}, \mathrm{t}}$ & Calculated \\
\hline IMR60 $_{i}$ & 1960 value of $I \mathrm{MR}_{\mathrm{i}, \mathrm{t}}$ & Calculated \\
\hline LIMR60 $_{\mathrm{i}}$ & Natural logarithm of LIMR60 $_{\mathrm{i}}$ & Calculated \\
\hline IMRDECL $_{i}$ & $\begin{array}{l}\text { Average annual rate of decline for country } \\
\text { i of IMR from } 1960 \text { to } 2000 \text {, expressed as } \\
\text { a percentage (decimal value multiplied by } \\
\text { 100) }\end{array}$ & Calculated \\
\hline EQTEST $_{\mathrm{i}}$ & $\begin{array}{l}\text { Average mathematics test score for } \\
\text { country } \mathrm{i}\end{array}$ & $\begin{array}{l}\text { Sources and methodology explained in } \\
\text { more detail in Annex B }\end{array}$ \\
\hline $\mathrm{EQBT}_{\mathrm{i}}$ & $\begin{array}{l}\text { Average of } 1980 \text { and } 1990 \text { value for US } \\
\text { labor market returns to an extra year of } \\
\text { schooling in country } i\end{array}$ & Bratsberg and Terrell (2002) \\
\hline OPEN $_{\mathrm{i}}$ & $\begin{array}{l}\text { Fraction of the years between } 1960 \text { and } \\
1998 \text { that country i was deemed to have } \\
\text { an economy open to international trade; } \\
\text { this was determined based on five factors } \\
\text { including tariffs, quotas, exchange rate } \\
\text { controls, export controls and whether or } \\
\text { not a socialist economy }\end{array}$ & $\begin{array}{l}\text { Harvard Center for International } \\
\text { Development, data provided by Gordon } \\
\text { McCord on behalf of Jeffrey Sachs; see } \\
\text { also Sachs and Warner (1997a and } \\
\text { 1997b) }\end{array}$ \\
\hline TROPICAL $_{i}$ & $\begin{array}{l}\text { Fraction of the land area of country } i \text { that is } \\
\text { located within the geographic tropics }\end{array}$ & $\begin{array}{l}\text { Harvard Center for International } \\
\text { Development, data provided by Gordon } \\
\text { McCord on behalf of Jeffrey Sachs; see } \\
\text { also Sachs and Warner (1997a and } \\
\text { 1997b) }\end{array}$ \\
\hline EQOPEN $_{\mathrm{i}}$ & EQTEST $_{i}$ * OPEN $N_{i}$ & Calculated \\
\hline
\end{tabular}


Table A.2a Variable Means and Standard Deviations: Time-Invariant Variables (Data Set Restricted to Countries With Valid EQTEST)

\begin{tabular}{|c|c|c|c|}
\hline Variable & $\mathrm{N}^{\mathrm{a}}$ & Mean & Std. Deviation \\
\hline $\mathrm{YPC60}_{\mathrm{i}}$ & 50 & 4.98 & 3.68 \\
\hline LYPC60 $_{i}$ & 50 & 8.20 & 0.84 \\
\hline $\mathrm{YPCGR}_{\mathrm{i}}$ & 46 & 2.55 & 1.37 \\
\hline $\mathrm{ED60}_{\mathrm{i}}$ & 54 & 5.48 & 2.97 \\
\hline TFRAVG $_{i}$ & 52 & 3.25 & 1.40 \\
\hline IMR60 $_{\mathrm{i}}$ & 52 & 73.39 & 54.53 \\
\hline LIMR60 $_{i}$ & 52 & 4.01 & 0.79 \\
\hline IMRDECL $_{i}$ & 52 & 3.98 & 1.27 \\
\hline EQTEST $_{\mathrm{i}}$ & 54 & 464.90 & 57.13 \\
\hline $\mathrm{EQBT}_{\mathrm{i}}$ & 45 & 4.87 & 1.26 \\
\hline OPEN $_{i}$ & 52 & 0.63 & 0.39 \\
\hline TROPICAL $_{i}$ & 53 & 0.27 & 0.41 \\
\hline EQOPEN $_{\mathrm{i}}$ & 52 & 304.81 & 201.40 \\
\hline
\end{tabular}

${ }^{\mathrm{a}} \mathrm{N}$ is the number of valid observations for this variable.

Table A.2b Variable Means and Standard Deviations: Time-Invariant Variables (Data Set Restricted to Countries With Valid EQBT)

\begin{tabular}{|c|c|c|c|}
\hline Variable & $\mathrm{N}^{\mathrm{a}}$ & Mean & Std. Deviation \\
\hline YPC60 & 58 & 4.41 & 3.61 \\
\hline LYPC60 $_{i}$ & 58 & 8.03 & 0.91 \\
\hline $\mathrm{YPCGR}_{\mathrm{i}}$ & 55 & 2.50 & 1.19 \\
\hline $\mathrm{ED60}_{\mathrm{i}}$ & 62 & 5.10 & 2.97 \\
\hline TFRAVG $_{i}$ & 61 & 3.59 & 1.54 \\
\hline IMR60 $_{i}$ & 61 & 82.05 & 54.39 \\
\hline LIMR60 $_{i}$ & 61 & 4.15 & 0.75 \\
\hline IMRDECL $_{i}$ & 61 & 3.81 & 1.29 \\
\hline EQTEST $_{\mathrm{i}}$ & 45 & 473.60 & 55.99 \\
\hline $\mathrm{EQBT}_{\mathrm{i}}$ & 62 & 4.41 & 1.42 \\
\hline OPEN $_{i}$ & 60 & 0.55 & 0.39 \\
\hline TROPICAL $_{i}$ & 62 & 0.42 & 0.47 \\
\hline EQOPEN $_{\mathrm{i}}$ & 44 & 327.35 & 197.44 \\
\hline
\end{tabular}

${ }^{\mathrm{a}} \mathrm{N}$ is the number of valid observations for this variable. 
Table A.3 Variable Means and Standard Deviations: Time-Varying Variables

(Data Set Restricted to Countries With Valid EQTEST)

\begin{tabular}{|c|c|c|c|c|c|c|c|c|c|}
\hline \multirow[b]{2}{*}{ Variable } & \multicolumn{3}{|c|}{ Overall } & \multicolumn{3}{|c|}{1960} & \multicolumn{3}{|c|}{2000} \\
\hline & $\mathrm{N}^{\mathrm{a}}$ & Mean & Std.Dev. & $\mathrm{N}^{\mathrm{a}}$ & Mean & Std.Dev. & $\mathrm{N}^{\mathrm{a}}$ & Mean & Std.Dev. \\
\hline$Y P C_{i, t}$ & 262 & 9,614 & 7,387 & 50 & 4,984 & 3,682 & 50 & 14,544 & 9,396 \\
\hline LYPC $_{i, t}$ & 262 & 8.81 & 0.94 & 50 & 8.20 & 0.84 & 50 & 9.27 & 0.93 \\
\hline$K P C_{i, t}$ & 262 & 22,020 & 20,225 & 50 & 11,081 & 9,926 & 50 & 33,882 & 26,113 \\
\hline $\operatorname{LKPC}_{i, t}$ & 262 & 9.38 & 1.34 & 50 & 8.72 & 1.30 & 50 & 9.91 & 1.29 \\
\hline LYMK $_{i, t}$ & 262 & 5.52 & 0.51 & 50 & 5.15 & 0.48 & 50 & 5.80 & 0.50 \\
\hline$E D_{i, t}$ & 270 & 7.48 & 3.29 & 54 & 5.48 & 2.97 & 54 & 9.38 & 2.73 \\
\hline $\mathrm{TFR}_{\mathrm{i}, \mathrm{t}}$ & 263 & 3.27 & 1.73 & 52 & 4.43 & 1.86 & 53 & 2.20 & 0.95 \\
\hline LTFR $_{i, t}$ & 263 & 1.06 & 0.50 & 52 & 1.40 & 0.43 & 53 & 0.71 & 0.38 \\
\hline$I M R_{i, t}$ & 264 & 42.78 & 43.24 & 52 & 73.39 & 54.53 & 53 & 20.00 & 24.16 \\
\hline
\end{tabular}

${ }^{\text {a }} \mathrm{N}$ is the number of valid observations for this variable. 
Table B.1: Country Specific Estimates of Years of Schooling

\begin{tabular}{|c|c|c|c|c|c|c|}
\hline \multirow[b]{2}{*}{ Country } & \multicolumn{5}{|c|}{ Years of Schooling (ED) ${ }^{a}$} & \multirow{2}{*}{$\begin{array}{l}\text { Imputed } \\
\text { from B- } \mathrm{L}^{\mathrm{b}}\end{array}$} \\
\hline & 1960 & 1970 & 1980 & 1990 & 2000 & \\
\hline Argentina & 6.13 & 6.76 & 7.52 & 7.69 & 8.30 & $\mathrm{~N}$ \\
\hline Australia & 9.82 & 11.04 & 12.20 & 12.76 & 13.09 & $\mathrm{~N}$ \\
\hline Austria & 8.28 & 9.28 & 10.31 & 10.94 & 11.43 & $\mathrm{~N}$ \\
\hline Belgium & 7.39 & 8.29 & 9.24 & 10.03 & 10.84 & $\mathrm{~N}$ \\
\hline Brazil & 3.07 & 3.69 & 4.27 & 6.53 & 7.50 & $\mathrm{~N}$ \\
\hline Botswana & 1.97 & 2.50 & 3.73 & 6.31 & 7.51 & $\mathrm{Y}$ \\
\hline Canada & 9.11 & 10.37 & 11.59 & 12.36 & 13.07 & $\mathrm{~N}$ \\
\hline Switzerland & 10.96 & 11.81 & 12.48 & 12.96 & 12.73 & $\mathrm{~N}$ \\
\hline Chile & 6.19 & 7.05 & 8.18 & 9.14 & 9.94 & $\mathrm{~N}$ \\
\hline China & 2.26 & 3.10 & 4.10 & 5.06 & 5.96 & $\mathrm{~N}$ \\
\hline Colombia & 3.70 & 4.30 & 4.89 & 6.03 & 7.13 & $\mathrm{~N}$ \\
\hline Costa Rica & 3.26 & 3.91 & 4.68 & 5.91 & 6.72 & $\mathrm{~N}$ \\
\hline Cyprus & 5.53 & 6.34 & 7.14 & 8.00 & 8.87 & $\mathrm{~N}$ \\
\hline Denmark & 9.08 & 10.08 & 11.03 & 11.54 & 12.20 & $\mathrm{~N}$ \\
\hline Dominican Republic & 2.52 & 3.54 & 4.05 & 4.90 & 5.88 & $\mathrm{~N}$ \\
\hline Ecuador & 4.29 & 5.15 & 6.26 & 7.21 & 8.22 & $\mathrm{~N}$ \\
\hline Egypt & 1.01 & 1.64 & 2.93 & 4.96 & 6.76 & $\mathrm{~N}$ \\
\hline Spain & 5.79 & 6.52 & 7.45 & 8.44 & 9.51 & $\mathrm{~N}$ \\
\hline Finland & 6.85 & 7.96 & 9.49 & 10.73 & 11.68 & $\mathrm{~N}$ \\
\hline France & 6.73 & 8.02 & 9.34 & 10.36 & 10.73 & $\mathrm{~N}$ \\
\hline United Kingdom & 9.11 & 10.32 & 11.57 & 12.28 & 13.13 & $\mathrm{~N}$ \\
\hline Germany & 9.52 & 11.14 & 12.65 & 13.21 & 12.95 & $\mathrm{~N}$ \\
\hline Ghana & 1.89 & 3.18 & 4.36 & 4.82 & 5.26 & $\mathrm{~N}$ \\
\hline Greece & 5.94 & 6.74 & 7.72 & 8.71 & 9.90 & $\mathrm{~N}$ \\
\hline Guatemala & 1.64 & 1.92 & 2.65 & 3.92 & 4.84 & $\mathrm{~N}$ \\
\hline Hong Kong & 5.82 & 7.36 & 9.12 & 10.56 & 11.00 & $Y$ \\
\hline Honduras & 1.90 & 3.39 & 4.10 & 4.64 & 5.32 & $\mathrm{~N}$ \\
\hline Haiti & 1.12 & 1.45 & 2.06 & 3.13 & 3.60 & $\mathrm{~N}$ \\
\hline Hungary & 7.57 & 8.33 & 9.32 & 10.10 & 10.87 & $\mathrm{~N}$ \\
\hline Indonesia & 1.60 & 2.89 & 3.80 & 5.99 & 7.25 & $\mathrm{~N}$ \\
\hline India & 1.17 & 1.95 & 2.61 & 3.15 & 4.34 & $\mathrm{~N}$ \\
\hline Ireland & 7.25 & 8.02 & 8.94 & 9.53 & 10.17 & $\mathrm{~N}$ \\
\hline Iran & 0.71 & 1.33 & 2.28 & 3.84 & 5.34 & $\mathrm{~N}$ \\
\hline Iceland & 6.51 & 7.63 & 8.47 & 9.41 & 10.35 & $Y$ \\
\hline Israel & 8.14 & 9.36 & 10.75 & 10.81 & 11.21 & $Y$ \\
\hline Italy & 5.82 & 6.79 & 7.96 & 9.10 & 10.33 & $\mathrm{~N}$ \\
\hline Jamaica & 4.83 & 5.77 & 7.24 & 8.09 & 8.66 & $\mathrm{~N}$ \\
\hline Jordan & 2.58 & 5.22 & 7.40 & 9.36 & 10.28 & $\mathrm{~N}$ \\
\hline Japan & 9.48 & 10.37 & 11.20 & 11.93 & 12.61 & $\mathrm{~N}$ \\
\hline Kenya & 1.86 & 2.80 & 3.99 & 5.24 & 6.06 & $\mathrm{~N}$ \\
\hline Korea, Republic of & 4.98 & 6.82 & 9.11 & 11.00 & 12.34 & $\mathrm{~N}$ \\
\hline Sri Lanka & 4.44 & 5.57 & 6.49 & 7.13 & 8.17 & $\mathrm{Y}$ \\
\hline Morocco & 0.61 & 0.95 & 1.51 & 2.41 & 3.58 & $\mathrm{~N}$ \\
\hline Mexico & 3.98 & 4.90 & 5.90 & 7.06 & 7.95 & $\mathrm{~N}$ \\
\hline Mozambique & 0.45 & 0.78 & 1.05 & 2.02 & 2.39 & $\mathrm{~N}$ \\
\hline Malaysia & 3.22 & 4.60 & 6.22 & 7.98 & 9.31 & $\mathrm{~N}$ \\
\hline Nigeria & 1.05 & 1.29 & 1.41 & 2.61 & 3.89 & $\mathrm{~N}$ \\
\hline Netherlands & 8.34 & 9.35 & 10.28 & 10.72 & 11.34 & $\mathrm{~N}$ \\
\hline Norway & 9.05 & 10.30 & 11.56 & 12.32 & 12.49 & $\mathrm{~N}$ \\
\hline New Zealand & 8.98 & 9.87 & 10.72 & 11.02 & 12.09 & $\mathrm{~N}$ \\
\hline Pakistan & 0.87 & 2.04 & 2.55 & 4.98 & 4.83 & Y \\
\hline Panama & 4.60 & 5.22 & 6.86 & 7.87 & 8.56 & $\mathrm{~N}$ \\
\hline Peru & 4.27 & 5.23 & 6.39 & 7.47 & 8.32 & $\mathrm{~N}$ \\
\hline Philippines & 4.45 & 5.28 & 6.26 & 7.17 & 7.94 & $\mathrm{~N}$ \\
\hline Poland & 7.87 & 9.14 & 10.04 & 10.92 & 11.48 & $Y$ \\
\hline Portugal & 3.16 & 4.11 & 5.57 & 5.91 & 7.28 & $\mathrm{~N}$ \\
\hline Romania & 7.23 & 7.48 & 8.31 & 9.18 & 10.00 & $\mathrm{~N}$ \\
\hline Singapore & 4.20 & 5.84 & 5.79 & 7.06 & 9.82 & $\mathrm{~N}$ \\
\hline Sierra Leone & 0.76 & 1.05 & 1.95 & 2.83 & 3.61 & $\mathrm{~N}$ \\
\hline El Salvador & 2.01 & 2.55 & 3.59 & 4.54 & 5.10 & $\mathrm{~N}$ \\
\hline Sweden & 8.69 & 9.97 & 11.26 & 12.04 & 11.72 & $\mathrm{~N}$ \\
\hline Thailand & 2.60 & 3.15 & 3.87 & 6.50 & 7.51 & $\mathrm{~N}$ \\
\hline Trinidad \& Tobago & 6.75 & 7.24 & 8.47 & 9.23 & 9.60 & $\mathrm{~N}$ \\
\hline Tunisia & 0.83 & 1.58 & 2.73 & 3.32 & 4.44 & $\mathrm{~N}$ \\
\hline Turkey & 2.14 & 3.07 & 4.16 & 5.23 & 6.25 & $\mathrm{~N}$ \\
\hline Taiwan & 4.36 & 6.25 & 8.74 & 9.26 & 10.28 & $\mathrm{Y}$ \\
\hline Tanzania & 2.03 & 2.00 & 2.08 & 2.88 & 3.47 & $\mathrm{~N}$ \\
\hline Uganda & 1.20 & 1.80 & 2.16 & 2.54 & 3.31 & $\mathrm{~N}$ \\
\hline Uruguay & 5.32 & 6.04 & 6.85 & 7.68 & 8.36 & $\mathrm{~N}$ \\
\hline USA & 10.18 & 11.27 & 12.19 & 12.62 & 12.63 & $\mathrm{~N}$ \\
\hline South Africa & 4.32 & 4.80 & 5.13 & 5.66 & 7.35 & $\mathrm{~N}$ \\
\hline
\end{tabular}

${ }^{a}$ Years of schooling is the average number of years of schooling among the population (male and female) between the ages of 15 and 64; except as noted, our source is Cohen and Soto (2001).

$\mathrm{b}$ "Y" indicates that we have used predicted values for this country, the procedure for generating these predicted values is described in more detail in the text preceding this table. 
Table B.2 U.S. Labor Market Earnings as an Indicator of Education

Quality in a Country - Bratsberg \& Terrell Data for 1980 and 1990

\begin{tabular}{|c|c|c|c|c|c|}
\hline \multirow[b]{2}{*}{ Country } & \multicolumn{2}{|c|}{ B\&T Coefficient ${ }^{a}$} & \multirow[b]{2}{*}{ Average } & \multirow{2}{*}{$\begin{array}{c}\% \text { Increase } \\
\text { as a } \% \text { of avg } \\
\text { Increase } \\
\end{array}$} & \multirow{2}{*}{$\begin{array}{c}\text { Test Score } \\
\text { Indicator of } \\
\text { Quality Available } \\
\end{array}$} \\
\hline & 1980 & 1990 & & & \\
\hline $\begin{array}{l}\text { Unweighted sample } \\
\text { average }(\mathrm{N}=62)\end{array}$ & 3.93 & 4.89 & 4.41 & $100 \%$ & \\
\hline Argentina & 4.36 & 5.06 & 4.71 & $66 \%$ & 1 \\
\hline Australia & 5.66 & 7.03 & 6.35 & $100 \%$ & 1 \\
\hline Austria & 5.33 & 6.99 & 6.16 & $129 \%$ & 1 \\
\hline Belgium & 5.84 & 6.90 & 6.37 & $75 \%$ & 1 \\
\hline Brazil & 4.96 & 4.17 & 4.57 & $-66 \%$ & 1 \\
\hline Canada & 5.55 & 6.85 & 6.20 & $97 \%$ & 1 \\
\hline Chile & 4.06 & 4.38 & 4.22 & $33 \%$ & 1 \\
\hline China & 2.47 & 2.74 & 2.61 & $45 \%$ & 1 \\
\hline Colombia & 2.83 & 3.32 & 3.08 & $72 \%$ & 1 \\
\hline Costa Rica & 2.96 & 3.77 & 3.37 & $113 \%$ & 0 \\
\hline Denmark & 5.90 & 6.92 & 6.41 & $71 \%$ & 1 \\
\hline Dominican Republic & 1.22 & 2.10 & 1.66 & $298 \%$ & 0 \\
\hline Ecuador & 2.20 & 2.77 & 2.49 & $107 \%$ & 0 \\
\hline El Salvador & 1.82 & 2.21 & 2.02 & $89 \%$ & 0 \\
\hline Egypt & 4.08 & 4.69 & 4.39 & $62 \%$ & 1 \\
\hline Finland & 4.90 & 6.71 & 5.81 & $153 \%$ & 1 \\
\hline France & 5.31 & 6.45 & 5.88 & $89 \%$ & 1 \\
\hline Germany & 5.09 & 6.35 & 5.72 & $102 \%$ & 1 \\
\hline Greece & 3.00 & 4.29 & 3.65 & $178 \%$ & 1 \\
\hline Guatemala & 2.00 & 2.14 & 2.07 & $29 \%$ & 0 \\
\hline Haiti & 1.19 & 2.02 & 1.61 & $288 \%$ & 0 \\
\hline Honduras & 2.54 & 2.34 & 2.44 & $-33 \%$ & 0 \\
\hline Hong Kong & 3.16 & 4.07 & 3.62 & $119 \%$ & 1 \\
\hline Hungary & 4.00 & 4.82 & 4.41 & $85 \%$ & 1 \\
\hline India & 3.82 & 4.76 & 4.29 & $102 \%$ & 0 \\
\hline Indonesia & 4.02 & 5.08 & 4.55 & $109 \%$ & 1 \\
\hline Iran & 4.77 & 4.91 & 4.84 & $12 \%$ & 1 \\
\hline Ireland & 4.29 & 5.87 & 5.08 & $152 \%$ & 1 \\
\hline Israel & 3.86 & 5.62 & 4.74 & $188 \%$ & 1 \\
\hline Italy & 4.42 & 5.42 & 4.92 & $93 \%$ & 1 \\
\hline Jamaica & 2.46 & 3.50 & 2.98 & $175 \%$ & 0 \\
\hline Japan & 5.22 & 8.22 & 6.72 & $237 \%$ & 1 \\
\hline Kenya & 4.40 & 5.60 & 5.00 & $113 \%$ & 0 \\
\hline Korea, R & 3.33 & 4.49 & 3.91 & $144 \%$ & 1 \\
\hline Malaysia & 3.17 & 4.39 & 3.78 & $159 \%$ & 1 \\
\hline Mexico & 2.48 & 2.03 & 2.26 & $-75 \%$ & 1 \\
\hline Morocco & 3.94 & 4.02 & 3.98 & $8 \%$ & 1 \\
\hline Netherlands & 5.11 & 6.54 & 5.83 & $116 \%$ & 1 \\
\hline New Zealand & 4.40 & 7.29 & 5.85 & $271 \%$ & 1 \\
\hline Norway & 6.32 & 7.89 & 7.11 & $103 \%$ & 1 \\
\hline Pakistan & 3.17 & 3.79 & 3.48 & $81 \%$ & 0 \\
\hline Panama & 3.72 & 3.64 & 3.68 & $-9 \%$ & 0 \\
\hline Peru & 3.01 & 3.20 & 3.11 & $26 \%$ & 1 \\
\hline Philippines & 2.69 & 3.44 & 3.07 & $115 \%$ & 1 \\
\hline Poland & 3.98 & 4.31 & 4.15 & $34 \%$ & 1 \\
\hline Portugal & 4.33 & 4.46 & 4.40 & $12 \%$ & 1 \\
\hline Romania & 4.14 & 5.01 & 4.58 & $87 \%$ & 1 \\
\hline Sierra Leone & 2.93 & 3.14 & 3.04 & $30 \%$ & 0 \\
\hline Singapore & 4.56 & 6.22 & 5.39 & $150 \%$ & 1 \\
\hline Spain & 4.24 & 5.18 & 4.71 & $92 \%$ & 1 \\
\hline Sri Lanka & 4.97 & 5.56 & 5.27 & $49 \%$ & 0 \\
\hline Sweden & 5.43 & 7.39 & 6.41 & $149 \%$ & 1 \\
\hline Switzerland & 6.30 & 7.16 & 6.73 & $56 \%$ & 1 \\
\hline Taiwan & 3.36 & 4.63 & 4.00 & $156 \%$ & 1 \\
\hline Tanzania & 2.81 & 4.39 & 3.60 & $232 \%$ & 0 \\
\hline Thailand & 2.52 & 3.41 & 2.97 & $146 \%$ & 1 \\
\hline Trinidad and Tobago & 2.70 & 3.75 & 3.23 & $161 \%$ & 0 \\
\hline Turkey & 4.34 & 5.44 & 4.89 & $105 \%$ & 1 \\
\hline Uganda & 3.82 & 4.72 & 4.27 & $97 \%$ & 0 \\
\hline United Kingdom & 5.60 & 7.03 & 6.32 & $106 \%$ & 1 \\
\hline Uruguay & 3.22 & 4.61 & 3.92 & $178 \%$ & 1 \\
\hline USA & 5.65 & 7.76 & 6.71 & $154 \%$ & 1 \\
\hline
\end{tabular}

Source: Bratsberg \& Terrell (2002)

${ }^{\mathrm{a}}$ The coefficients reported in this column are the estimated percentage changes in annual earnings in the US labor market associated with one additional year of education for an individual who received his or her education in the indicated country, after controlling for other potential determinants.

${ }^{\text {b }}$ A value of "1" in this column indicates that mathematics test score data were available for this country;

"0" indicates that they were not. 
Table C1: Comparison of Aggregate with Individual

Returns to a Year of Schooling for 44 Countries

\begin{tabular}{|c|c|c|c|}
\hline Country & $\begin{array}{l}\text { Aggregate } \\
\text { Returns }^{\mathrm{a}}\end{array}$ & $\begin{array}{l}\text { Individual } \\
\text { Returns }^{\text {b }}\end{array}$ & Difference \\
\hline Mean & $8.3 \%$ & $8.9 \%$ & \\
\hline Standard Deviation & $5.6 \%$ & $3.5 \%$ & \\
\hline Argentina & $4.5 \%$ * & $10.3 \%$ & $-5.8 \%$ \\
\hline Australia & $9.3 \%$ & $8.0 \%$ & $1.3 \%$ \\
\hline Austria & $10.1 \%$ & $7.2 \%$ & $2.9 \%$ \\
\hline Belgium & $12.2 \%$ * & $10.7 \%$ & $1.5 \%$ \\
\hline Botswana & $14.4 \%$ * & $19.1 \%$ & $-4.7 \%$ \\
\hline Brazil & $5.8 \%$ & $14.7 \%$ & $-8.9 \%$ \\
\hline Canada & $8.1 \%$ & $8.9 \%$ & $-0.8 \%$ \\
\hline Chile & $8.4 \%$ & $12.0 \%$ & $-3.6 \%$ \\
\hline China & $15.9 \%$ * & $12.2 \%$ & $3.7 \%$ \\
\hline Colombia & $5.1 \%$ & $14.0 \%$ & $-8.9 \%$ \\
\hline Cyprus & $20.4 \%$ * & $5.2 \%$ & $15.2 \%$ \\
\hline Denmark & $9.3 \%$ & $4.5 \%$ & $4.8 \%$ \\
\hline Egypt & $4.3 \%$ * & $5.2 \%$ & $-0.9 \%$ \\
\hline Finland & $10.4 \%$ & $8.2 \%$ & $2.2 \%$ \\
\hline France & $9.1 \%$ & $10.0 \%$ & $-0.9 \%$ \\
\hline Ghana & $12.8 \%$ * & $7.1 \%$ & $5.7 \%$ \\
\hline Greece & $8.7 \%$ & $7.6 \%$ & $1.1 \%$ \\
\hline Hong Kong & $19.3 \%$ * & $6.1 \%$ & $13.2 \%$ \\
\hline Hungary & $7.4 \%$ & $4.3 \%$ & $3.1 \%$ \\
\hline Indonesia & $5.4 \%$ & $7.0 \%$ & $-1.6 \%$ \\
\hline Iran & $-0.6 \%$ * & $11.6 \%$ & $-12.2 \%$ \\
\hline Ireland & $16.0 \%$ * & N/A & N/A \\
\hline Israel & $12.7 \%$ * & $6.4 \%$ & $6.3 \%$ \\
\hline Italy & $9.6 \%$ & $2.7 \%$ & $6.9 \%$ \\
\hline Japan & $11.4 \%$ & $13.2 \%$ & $-1.8 \%$ \\
\hline Jordan & $-2.9 \%$ * & $\mathrm{N} / \mathrm{A}$ & N/A \\
\hline Korea, Republic of & $9.4 \%$ & $13.5 \%$ & $-4.1 \%$ \\
\hline Malaysia & $7.7 \%$ & $9.4 \%$ & $-1.7 \%$ \\
\hline Mexico & $3.0 \%$ * & $7.6 \%$ & $-4.6 \%$ \\
\hline Morocco & $8.8 \%$ & $15.8 \%$ & $-7.0 \%$ \\
\hline Mozambique & $-4.1 \%$ * & N/A & $\mathrm{N} / \mathrm{A}$ \\
\hline Netherlands & $10.1 \%$ & $6.4 \%$ & $3.7 \%$ \\
\hline New Zealand & $5.7 \%$ & N/A & N/A \\
\hline Nigeria & $-7.6 \%$ * & N/A & N/A \\
\hline Norway & $11.4 \%$ & $5.5 \%$ & $5.9 \%$ \\
\hline Peru & $2.0 \%$ * & $8.1 \%$ & $-6.1 \%$ \\
\hline Philippines & $1.4 \%$ * & $12.6 \%$ & $-11.2 \%$ \\
\hline Poland & $6.5 \%$ & $7.0 \%$ & $-0.5 \%$ \\
\hline Portugal & $10.7 \%$ & $8.6 \%$ & $2.1 \%$ \\
\hline Romania & $12.7 \%$ * & N/A & N/A \\
\hline Singapore & $20.9 \%$ * & $13.1 \%$ & $7.8 \%$ \\
\hline South Africa & $3.0 \%$ * & $4.1 \%$ & $-1.1 \%$ \\
\hline Spain & $9.1 \%$ & $7.2 \%$ & $1.9 \%$ \\
\hline Sweden & $9.9 \%$ & $5.0 \%$ & $4.9 \%$ \\
\hline Switzerland & $8.3 \%$ & $7.5 \%$ & $0.8 \%$ \\
\hline Thailand & $10.2 \%$ & $11.5 \%$ & $-1.3 \%$ \\
\hline Tunisia & $11.1 \%$ & $8.0 \%$ & $3.1 \%$ \\
\hline Turkey & $1.8 \%$ * & $\mathrm{N} / \mathrm{A}$ & N/A \\
\hline United Kingdom & $7.4 \%$ & $6.8 \%$ & $0.6 \%$ \\
\hline Uruguay & $7.1 \%$ & $9.7 \%$ & $-2.6 \%$ \\
\hline USA & $11.6 \%$ & $10.0 \%$ & $1.6 \%$ \\
\hline
\end{tabular}

Note: the $95 \%$ confidence interval for the mean value of the coefficient on education (aggregate returns) is $5.1 \%$ to $11.6 \% ; 21$ of the 51 countries in our sample had estimated aggregate returns that are outside this range.

* Denotes a country whose estimated aggregate return is outside the $95 \%$ confidence interval, suggesting that its return is highly likely to be above (or below) the average.

a These country-specific estimates of the effects of a year of education on aggregate income levels come from Model 13 in Table 2.

${ }^{b}$ These estimates of the effect of a year of education on individual earnings were compiled by Psacharopoulos and Patrinos (undated). 
Table C2: Country-Specific Estimates of the Impact of Education on IMR

\begin{tabular}{|c|c|}
\hline Country & $\begin{array}{c}\text { Coefficient } \\
\text { on Education }^{\text {a }} \\
\end{array}$ \\
\hline Mean & $-13.9 \%$ \\
\hline Standard Deviation & $8.8 \%$ \\
\hline Argentina & $-13.7 \%$ \\
\hline Australia & $-12.9 \%$ \\
\hline Austria & $-24.1 \%$ * \\
\hline Belgium & $-20.1 \%$ * \\
\hline Botswana & $2.8 \%$ * \\
\hline Brazil & $-6.3 \%$ * \\
\hline Canada & $-16.5 \%$ \\
\hline Chile & $-32.3 \%$ * \\
\hline China & $-6.0 \%$ * \\
\hline Colombia & $-16.6 \%$ \\
\hline Cyprus & $-10.8 \%$ \\
\hline Denmark & $-17.4 \%$ \\
\hline Egypt & $-8.7 \%$ * \\
\hline Finland & $-13.6 \%$ \\
\hline France & $-18.2 \%$ \\
\hline Ghana & $-0.7 \%$ * \\
\hline Greece & $-23.1 \%$ * \\
\hline Hong Kong & $-22.4 \%$ * \\
\hline Hungary & $-17.3 \%$ \\
\hline Indonesia & $-2.7 \%$ * \\
\hline Iran & $-15.0 \%$ \\
\hline Ireland & $-17.3 \%$ \\
\hline Israel & $-16.4 \%$ \\
\hline Italy & $-23.1 \%$ * \\
\hline Japan & $-23.8 \%$ * \\
\hline Jordan & $-4.1 \%$ * \\
\hline Korea, Republic of & $-13.6 \%$ \\
\hline Malaysia & $-16.2 \%$ \\
\hline Mexico & $-6.0 \%$ * \\
\hline Morocco & $-10.1 \%$ \\
\hline Mozambique & $1.3 \%$ * \\
\hline Netherlands & $-13.5 \%$ \\
\hline New Zealand & $-14.8 \%$ \\
\hline Nigeria & $-3.4 \%$ * \\
\hline Norway & $-13.9 \%$ \\
\hline Peru & $-12.8 \%$ \\
\hline Philippines & $-10.0 \%$ \\
\hline Poland & $-16.3 \%$ \\
\hline Portugal & $-35.1 \%$ * \\
\hline Romania & $-8.3 \%$ * \\
\hline Singapore & $-20.6 \%$ * \\
\hline South Africa & $11.0 \%$ * \\
\hline Spain & $-32.2 \%$ * \\
\hline Sweden & $-15.8 \%$ \\
\hline Switzerland & $-19.0 \%$ * \\
\hline Thailand & $-2.0 \%$ * \\
\hline Tunisia & $-22.4 \%$ * \\
\hline Turkey & $-15.8 \%$ \\
\hline United Kingdom & $-12.3 \%$ \\
\hline Uruguay & $-12.9 \%$ \\
\hline USA & $-11.8 \%$ \\
\hline
\end{tabular}

Note: the $95 \%$ confidence interval for the mean value of the coefficient on education is $-18.3 \%$ to $-9.4 \%$; 25 of the 51 countries in our sample had estimated aggregate returns that are outside this range.

* Denotes a country whose estimated coefficient is outside the $95 \%$ confidence interval, suggesting that its return is highly likely to be above (or below) the average.

${ }^{a}$ These country-specific estimates of the effects of a year of education on the infant mortality rate (IMR) come from Model 24 in Table 5. 
Table D1: Education and Education Quality as Determinants of the Rate of Decline of Infant Mortality, 1960-2000

\begin{tabular}{|c|c|c|c|c|c|c|}
\hline \multirow[b]{2}{*}{ Variable } & \multicolumn{6}{|c|}{ Models } \\
\hline & 29 & 30 & 31 & 32 & 33 & 34 \\
\hline Constant & $\begin{array}{l}5.325 \\
(4.75)\end{array}$ & $\begin{array}{l}0.105 \\
(0.05)\end{array}$ & $\begin{array}{l}0.306 \\
(0.14)\end{array}$ & $\begin{array}{l}7.038 \\
(1.49)\end{array}$ & $\begin{array}{r}-9.567 \\
(1.59)\end{array}$ & $\begin{array}{r}-15.098 \\
(2.36)\end{array}$ \\
\hline YPC60 & $\begin{array}{r}-0.197 \\
(2.19)\end{array}$ & $\begin{array}{r}-0.168 \\
(2.00)\end{array}$ & $\begin{array}{r}-0.189 \\
(2.30)\end{array}$ & & & \\
\hline IMR60 & $\begin{array}{r}-0.0136 \\
(2.10)\end{array}$ & $\begin{array}{r}-0.0066 \\
(1.01)\end{array}$ & $\begin{array}{r}0.0010 \\
(0.14)\end{array}$ & & & \\
\hline LYPC60 & & & & $\begin{array}{r}-0.208 \\
(0.48)\end{array}$ & $\begin{array}{l}0.427 \\
(1.03)\end{array}$ & $\begin{array}{l}0.551 \\
(1.37)\end{array}$ \\
\hline LIMR60 & & & & $\begin{array}{r}-0.440 \\
(0.83)\end{array}$ & $\begin{array}{l}0.680 \\
(1.24)\end{array}$ & $\begin{array}{l}1.654 \\
(2.65)\end{array}$ \\
\hline ED60 & $\begin{array}{l}0.111 \\
(0.70)\end{array}$ & $\begin{array}{l}0.085 \\
(0.58)\end{array}$ & $\begin{array}{l}0.115 \\
(0.79)\end{array}$ & $\begin{array}{l}0.066 \\
(0.44)\end{array}$ & $\begin{array}{l}0.013 \\
(0.10)\end{array}$ & $\begin{array}{l}0.085 \\
(0.66)\end{array}$ \\
\hline EQTEST & & $\begin{array}{r}0.0101 \\
(2.85)\end{array}$ & $\begin{array}{r}0.0064 \\
(1.74)\end{array}$ & & $\begin{array}{r}0.0155 \\
(3.79)\end{array}$ & $\begin{array}{r}0.0130 \\
(3.16)\end{array}$ \\
\hline OPEN & & & $\begin{array}{l}1.671 \\
(2.82)\end{array}$ & & & $\begin{array}{l}2.135 \\
(3.69)\end{array}$ \\
\hline TROPICAL & & & $\begin{array}{r}-0.453 \\
(1.02)\end{array}$ & & & $\begin{array}{r}-0.011 \\
(0.03)\end{array}$ \\
\hline $\mathrm{N}$ & 47 & 47 & 46 & 47 & 47 & 46 \\
\hline R-Squared & 0.245 & 0.365 & 0.476 & 0.090 & 0.318 & 0.496 \\
\hline
\end{tabular}

Notes: $\quad$ 1. The dependent variable is IMRDECL, i.e. the annual rate of decline in a country's infant mortality rate expressed in \% per year.

2. $t$-values are shown in parenthesis below the estimated coefficients. 